\title{
Um caminho metodológico pela análise semiótica de discurso para pesquisas em identidade organizacional
}

\author{
Marco antonio Fernandes Cardoso \\ Fundação GETULIO VARGAS / FGV MANAGEMENT (MBA), RIO DE JANEIRO - RJ, BRASIL
}

DARCY MITIKO MORI HANASHIRO

Universidade Presbiteriana Mackenzie / Centro de Ciências Sociais e Aplicadas, Programa de Pós-Graduação em AdMINISTRAÇÃO DE EMPRESAS, SÃO PAULO - SP, BRASIL

Diana luz Pessoa de Barros

Universidade Presbiteriana Mackenzie / Centro de Comunicação e letras, Programa de Pós-Graduação em Letras, SÃO PAULO - SP, BRASIL

\begin{abstract}
Resumo
Este artigo propõe um percurso metodológico baseado na análise semiótica dos discursos organizacionais, inspirada em Greimas, para a condução de pesquisas sobre identidade organizacional (IO). A primazia dessa abordagem consiste em seu potencial para aprofundar a compreensão das características definidoras do conceito seminal de IO, introduzido inicialmente por Albert e Whetten (1985). Escassas são as pesquisas nacionais e estrangeiras que adotam a perspectiva da semiótica discursiva de texto. Os estudos sobre IO no Brasil empregam, predominantemente, algumas técnicas de análise, como: análise do discurso na linha francesa ou crítica, análise de conteúdo e outras genericamente denominadas análise interpretativa de dados textuais. Tais análises apresentam limitações metodológicas na apreensão do conceito de IO. Como contribuição teórica, a análise semiótica do discurso, conforme proposto neste artigo, permite avançar na compreensão do conceito de IO, por meio da análise dos relacionamentos binários de oposição, de contradição e de complementaridade, fornecido pelo quadrado semiótico.
\end{abstract}

Palavras-chave: Análise semiótica de discurso. Identidade organizacional. Quadrado semiótico.

\section{The methodological pathway through the semiotic analysis of discourse to research organizational identity}

\section{Abstract}

This article proposes a methodological pathway based on a semiotic analysis of organizational discourses, inspired by Greimas, to carry out research on organizational identity $(\mathrm{OI})$. The primacy of this approach consists of its potential to deepen the understanding of defining characteristics of the seminal concept of Ol, firstly introduced by Albert and Whetten (1985). There is a small body of Brazilian and foreign research that adopt the perspective of discursive text semiotic. In Brazil, the studies on OI predominantly employ some analysis techniques, such as: discourse analysis through the French or critical approach, content analysis, and other ones generically named as interpretative analysis of textual data. Such analysis has methodological limitations to apprehend the concept of OI. As a theoretical contribution, the semiotic analysis of discourse, as proposed in this article, allows advancing to understand the concept of Ol, by analyzing binary relationships of opposition, contradiction, and complementarity, provided by the semiotic square.

Keywords: Semiotic analysis of discourse. Organizational identity. Semiotic square.

Un enfoque metodológico por medio del análisis semiótico de discurso para investigaciones sobre identidad organizacional

\section{Resumen}

Este artículo propone un enfoque metodológico basado en el análisis semiótico de los discursos organizacionales, inspirado en Greimas, para llevar a cabo la investigación sobre la identidad organizacional (IO). La primacía de este enfoque es su potencial para profundizar la comprensión de las características que definen el concepto seminal de la IO, introducido originalmente por Albert y Whetten (1985). Pocas son las investigaciones nacionales y extranjeras que adoptan la perspectiva de la semiótica discursiva del texto. Los estudios de IO en Brasil emplean predominantemente algunas técnicas de análisis, como: el análisis de discurso en la línea francesa o crítica, el análisis de contenido y otras, genéricamente denominadas análisis interpretativo de datos textuales. Estos análisis tienen limitaciones metodológicas en captar el concepto de IO. Como aporte teórico, el análisis semiótico de discurso que se propone en este artículo permite avanzar en la comprensión del concepto de IO, mediante el análisis de las relaciones binarias de oposición, de contradicción y de complementariedad, proporcionado por el cuadrado semiótico.

Palabras clave: Análisis semiótico del discurso. Identidad organizacional. Cuadrado semiótico.

Artigo submetido em 2 de abril de 2014 e aceito para publicação em 27 de julho de 2015.

DOI: http://dx.doi.org/10.1590/1679-395118952 


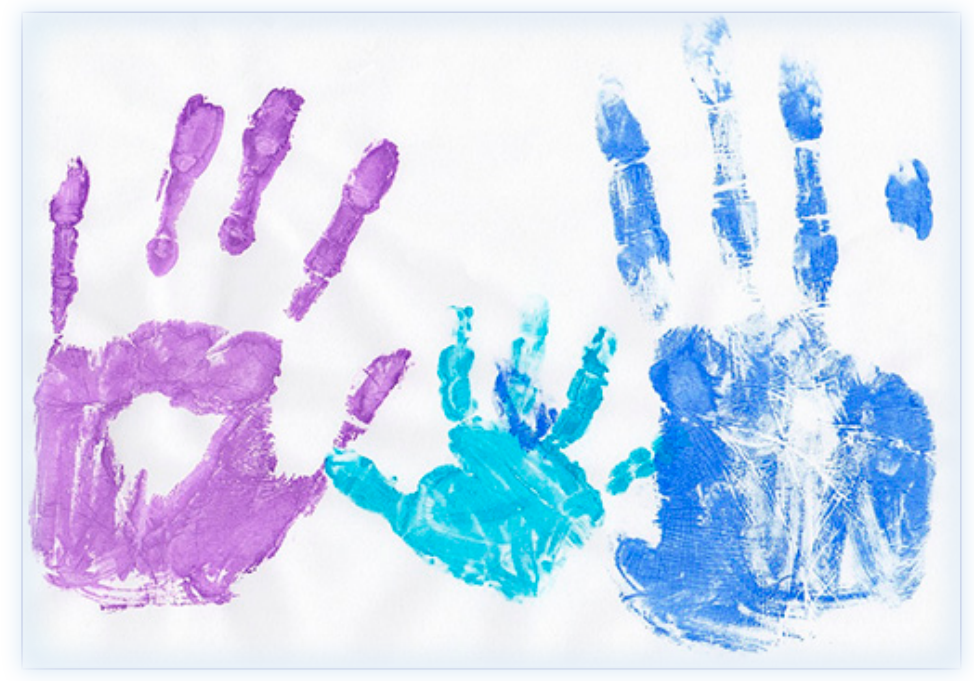

\section{INTRODUÇÃO}

Identidade é um dos mais populares tópicos nos estudos organizacionais contemporâneos, bem como em outras áreas de conhecimento das ciências sociais (SVENINGSSON e ALVESSON, 2003). Esse reconhecimento tem seu fundamento no papel apontado por Patvardhan, Gioia e Hamilton (2015) em que a identidade pode ser vista como um conceito-chave que molda, sustenta e conduz indivíduos em qualquer sistema social, como também no nível coletivo. No campo dos estudos organizacionais, Albert e Whetten (1985) introduzem o conceito de identidade organizacional (IO) como um conjunto de crenças partilhadas por seus membros sobre aspectos vistos como a essência da organização (centralidade), aspectos que distinguem a organização de outras (distinção) e aspectos que a organização ou seus membros desejam manter ao longo do tempo (continuidade). Depois do trabalho seminal de Albert e Whetten, o primeiro estudo empírico surgiu em $1991 \mathrm{com}$ a pesquisa de Dutton e Dukerich. Apesar de o conceito ter sido formulado há 30 anos, a pesquisa em IO teve seu grande impulso nos últimos 15 anos. Ravasi e Canato (2013, p. 185) observam que "a multiplicidade e relativa convergência dos esforços [dos estudos] para refinar o vocabulário relacionado à 10 e integrar perspectivas complementares indicam a crescente legitimação e consolidação da IO como um constructo central nos estudos organizacionais".

Uma investigação no sistema Scientific Periodicals Electronic Library (SPELL) e na base Scientific Electronic Library Online (SCIELO) foi conduzida com o duplo objetivo de examinar a publicação nacional em IO, bem como a metodologia empregada nas pesquisas. A busca revelou uma produção restrita de 14 artigos. A maioria desses trabalhos empíricos usou técnicas convencionais de categorização; apenas 2 empregaram a análise do discurso. Ravasi e Canato (2013) revisaram 33 estudos empíricos no tema IO publicados em revistas acadêmicas internacionais de alto impacto. As abordagens metodológicas adotadas para análise dos dados diferem substancialmente daquelas em geral aplicadas pelos pesquisadores no Brasil. Em 17 artigos a pesquisa de campo foi conduzida pela abordagem da teoria fundamentada. Nenhum autor declarou explicitamente o uso de análise do discurso. Um sumário desse levantamento é apresentado neste artigo na seção dedicada ao tema da IO.

Como foi constatado anteriormente o desenvolvimento no campo de IO revela maior embasamento empírico nos estudos internacionais. É importante salientar que o conceito seminal de 10 tem provocado múltiplas reações de pesquisadores consagrados na literatura, sobretudo em relação a seu aspecto de durabilidade. Nos últimos anos, vem crescendo o interesse pelas perspectivas dinâmica e plural da IO (FERNANDES, MARQUES e CARRIERI, 2009). O debate em torno do conceito de IO em busca de um aprofundamento teórico, somado ao argumento de que a IO é construída pela identidade discursiva, evidencia a necessidade de avançar na direção de propostas analíticas condizentes com os debates contemporâneos acerca da

* Fonte da imagem: Disponível em <https://pixabay.com/pt/m\%C3\%A3os-pessoal-humanos-cor-fam\%C3\%ADlia-1191449/ > Acesso em 14 mar. 2016. 
IO. Faz sentido, assim, explorar abordagens metodológicas que permitam revelar tanto aspectos menos evidentes e até ambíguos e fluidos da 10 quanto um ferramental analítico condizente para apreender o significado dos elementos discursivos dos diversos atores sociais na constituição da IO. Por essa lógica, entendemos que a teoria semiótica provê uma fundamentação metodológica defensável para as questões apontadas.

A semiótica, como teoria da significação, preocupa-se com as condições de "apreensão e produção do sentido" (GREIMAS e COURTÉS, 2011, p. 455). Apresenta como objeto o texto e procura descrever e explicar "o que o texto diz e como ele faz para dizer o que diz" (BARROS, 1997, p. 7). Para isso, dispõe do percurso gerativo do sentido, estabelecido em três níveis: o fundamental, o narrativo e o discursivo. Na perspectiva aqui defendida de 10 , dinâmica e fluida, argumenta-se que a análise semiótica greimasiana do discurso consiste em um recurso metodológico propício, pois permite o estudo da identidade e suas oposições semânticas.

A fim de explorar os usos da semiótica no campo dos estudos organizacionais e em administração, uma revisão da literatura nacional no sistema SPELL foi feito usando os termos "semiótica" e "semiótico". Este levantamento apresentou doze artigos, sendo oito empíricos, um estudo bibliográfico e três ensaios teóricos. Os estudos empíricos abordaram diferentes temáticas. Pessôa, Costa e Espírito Santo (2015) procederam a uma aplicação do modelo teórico clássico da semiótica discursiva de linha francesa para identificar as estratégias narrativas e discursivas adotadas pela revista Exame em seu discurso sobre as comunidades sociais virtuais; Sant'ana e Pessôa (2013) analisaram a identidade da marca brasileira de acessórios de moda Chilli Beans; Miguel e Popadiuk (2014) estudaram o compartilhamento do conhecimento tácito; Miranda, Kataoka, Santos et al. (2011) aplicaram a semiótica em estudos na área de contabilidade; Faria e Carvalho (2010) investigaram os processos de significação resultantes da exposição de consumidores a imagens de atletas paraolímpicos; Carvalho, Costa, Faria et al. (2010) apresentaram evidências simbólicas do processo de institucionalização a que são submetidos estudantes de Administração durante sua formação universitária; Rissoni (2007) investigou os procedimentos argumentativos empregados pelo sujeito produtor do discurso e a relação que se estabelece entre enunciador e enunciatário na configuração discursiva dos blogues. Ipiranga (2005) analisou como o docente pode usar os recursos audiovisuais, participando do processo de atribuição de significados possíveis. Esse levantamento mostrou dois trabalhos de um mesmo autor (Pessôa), sob a perspectiva da semiótica discursiva de linha francesa greimasiana. Nenhum artigo empírico ou teórico abordou IO ou temas correlatos.

Similarmente, o uso da análise semiótica greimasiana na literatura internacional tem sido consideravelmente limitado (ROBICHAUD, 2002). No campo dos estudos organizacionais, Robichaud (2002) mostra como a teoria semiótica pode contribuir para a conceptualização da ação organizacional. O autor conduziu um estudo de campo em uma administração municipal canadense empregando a gramática narrativa desenvolvida por Greimas, em que a estrutura narrativa é responsável pelo significado de qualquer texto. O nível fundamental, com a geração do quadrado semiótico, tem demonstrado utilidade para analisar o discurso do consumidor (FLOCH, 2014); especificamente para mapear as percepções de consumidores, posicionamento de produtos e construção de estratégias de marketing (MICK e OSWALD, 2006). Por exemplo, Dano, Roux e Nyeck (2003) investigaram a percepção e as atitudes dos consumidores em relação ao cosmético masculino; Kessous e Roux (2008) também usaram a estrutura de Greimas para mapear o significado de nostalgia para consumidores ao longo das dimensões de continuidade e descontinuidade. No domínio de estudos em Estratégia, Fiol (1989) adota o método semiótico de análise de textos, examinando relatórios de CEOs de companhias do setor químico norte-americano, objeto de um processo de joint venture. Na área de Recursos Humanos, Fisher (2005) usou o quadrado semiótico como ferramenta para elaborar uma matriz descritiva dos papéis de Desenvolvimento de Recursos Humanos e quatro posturas éticas. Barley (1983) conduziu uma investigação em uma casa funerária e mostrou como a pesquisa semiótica pode elucidar regras pelas quais membros de uma cultura de trabalho consistente e coerentemente geram significados. A análise semiótica promovida nesses estudos permitiu revelar facetas menos evidentes dos fenômenos investigados por meio da análise das relações de contradições e oposições.

Este artigo defende que a teoria semiótica do discurso pode consistir em um recurso metodológico de grande utilidade na compreensão mais profunda da construção da IO, por meio da análise textual dos níveis fundamental, narrativo e discursivo. Por último, o quadrado semiótico possibilita analisar as relações binárias de oposição, contradição e complementaridade subjacentes à identidade. 
Portanto, este artigo objetiva propor um caminho metodológico baseado na análise semiótica dos discursos organizacionais para estudos do tema IO.

A principal contribuição deste estudo é de natureza metodológica, ao prover uma ferramenta analítica para os estudos em IO: a análise semiótica do discurso. A análise do percurso gerativo do sentido, no plano de conteúdo, possibilita uma apreensão mais profunda da identidade. Apresenta no nível das estruturas fundamentais as oposições semânticas em relação à identidade e no nível das estruturas narrativas uma base para a compressão da construção e da formação da IO. As estruturas narrativas convertem-se em estruturas discursivas quando assumidas pelo sujeito da enunciação, que escolherá recursos para determinar as condições de produção do texto. Isso significa como a identidade é expressa, partindo de uma perspectiva de constituição da identidade discursiva. Não obstante, é pertinente destacar que essa proposta metodológica não se restringe unicamente ao campo de estudos da IO. O leitor, ao habilitar-se conceitualmente nessa perspectiva analítica, pode explorar seu domínio em outras temáticas, como culturas da organização e estudo crítico sobre práticas da diversidade, entre outras. Enfim, a potencialidade dessa proposta metodológica está para ser explorada e faz sentido quando o foco de interesse for o de compreender a construção de um discurso.

Este ensaio teórico se compõe, além desta introdução, de seis tópicos. O primeiro consiste em uma apresentação das principais abordagens de identidade. O segundo, aborda a relação entre identidade, discurso e semiótica. A seguir, a teoria semiótica do discurso desenvolvida por Greimas e seus três níveis: fundamental, narrativo e discursivo, além do quadrado semiótico. A seguir, apresentar-se-á uma articulação entre a abordagem do discurso e a IO. No quinto tópico, propõe-se um caminho metodológico de análise semiótica do discurso, ou seja, como aplicar essa análise nas pesquisas sobre IO. Para tornar concreta a proposta analítica, usa-se uma narrativa fictícia, porém, baseada em uma situação real, que ilustra a análise apresentada. As considerações finais lançam luzes diante da potencialidade desta investigação, resultando em um recurso metodológico para pesquisar e compreender os aspectos do caráter transitório e do conceito dinâmico e fluido da IO.

\section{IDENTIDADE ORGANIZACIONAL: MÚLTIPLOS OLHARES}

Os estudos empíricos no campo da IO começaram com os trabalhos dos autores Dutton e Dukerich (1991) e Gioia e Chittipeddi (1991), conforme constatado por Souza, Carrieri e Faria (2008). Em 1996, Elsbach e Kramer verificaram que a teoria e a pesquisa sobre 10 encontravam-se em seu estágio inicial. Nos anos subsequentes, assistiu-se a uma evolução conceitual tanto em IO quanto em temas correlatos (por exemplo, imagem, identificação). Nesse sentido, Gioia, Price, Hamilton et al. (2010, p. 1) pontuam que o estudo da IO "agora representa um domínio próspero entre teóricos e pesquisadores organizacionais".

Gioia (1998) destaca três diferentes perspectivas para a compreensão de IO abordadas na literatura. A visão funcionalista considera a identidade algo relativamente estável, de modo que o atributo durável permite comparações ao longo do tempo. Pode ser vista como uma variável com relação causal com outras variáveis e um fator para ser controlado para melhorar o desempenho da organização. A lente interpretativa tipicamente é uma abordagem subjetiva ou construcionista, em que a identidade é entendida como uma noção "social e simbolicamente construída a fim de atribuir significado à experiência". Assim, o aspecto central da abordagem é "a descrição e a explicação compreensiva de identidade, com a intenção de compreender o sistema de significado empregado pelos membros da organização e outros constituintes relevantes" (GIOIA, 1998, p. 27). À luz da visão pós-moderna, a IO é um considerável dilema. Os pós-modernistas questionam a existência de uma identidade racional e coerente. Com isso, não necessariamente discordam dos interpretativistas de que a identidade é socialmente construída, mas argumentam que, em razão de sua absoluta construção, a identidade se torna um mito, uma "ilusão" e, assim, colocam em dúvida a própria existência da identidade. Estudiosos alinhados a essa perspectiva reconhecem a noção de uma organização composta por numerosas identidades e frequentemente incongruentes.

A despeito da inquestionável contribuição teórica de Albert e Whetten (1985), Albert (1998) e Whetten (2006), pesquisadores questionam o conceito de IO, baseados nos aspectos de centralidade, distinção e durabilidade. Nos últimos anos vem crescendo o interesse dos estudiosos pelas perspectivas dinâmica e plural da IO (FERNANDES, MARQUES e CARRIERI, 2009). Em artigo recente, Gioia, Patvardhan, Hamilton et al. (2013) confirmam o que há décadas pesquisadores vêm apontando, de que o mais controvertido aspecto da IO diz respeito a seu atributo de estabilidade ao longo do tempo. Com base nessa crítica os autores propõem uma identidade dinâmica. 
"Identidade nas organizações", "identidade com a organização", identificação" e "imagem” são termos que aparecem recorrentemente na literatura. Teoria e pesquisas sugerem que a identidade individual e a organizacional estão intimamente ligadas (ASHFORTH e MAEL, 1989; DUTTON, DUKERICH e HARQUAIL, 1994; ELSBACH e KRAMER, 1996) da mesma forma como imagem organizacional e IO (DUTTON e DUKERICH, 1991; HATCH e SCHULTZ, 1997). Os aspectos de distinção da IO estão relacionados à percepção de exclusividade da organização, referência para garantir a identificação (ASHFORTH e MAEL, 1989).

IO e identificação constituem conceitos nem sempre claramente definidos na literatura. O conceito de Dutton, Dukerich e Harquail (1994), ancorado em percepção, ajuda a esclarecer esses conceitos. Os autores definem IO como percepções dos membros da organização acerca dos traços central, distintivo e duradouro de suas organizações; ressaltam, também, a importância de distinguir entre dois tipos de percepções de identidade: 1) a IO percebida: o que um membro da organização acredita que são atributos centrais, distintivos e duradouros de sua organização; 2) identidade externa construída: o que um membro da organização acredita que membros externos (outsiders) pensam que são atributos centrais, distintivos e duradouros de sua organização. Enquanto uma IO é coletiva e representa um conjunto de crenças que os membros compartilham, a IO percebida refere-se às crenças de um indivíduo particular. Quando o autoconceito de um indivíduo contém os mesmos atributos da IO percebida, então a essa conexão cognitiva Dutton, Dukerich e Harquail (1994) chamam de identificação organizacional.

O ambiente desempenha um papel importante na compreensão sobre IO. A identidade e a imagem organizacional são construções críticas e dinâmicas diretamente relacionadas às interpretações e reações organizacionais ao seu ambiente (DUTTON e DUKERICH, 1991). Elsbach e Kramer (1996, p. 442) conduziram um estudo com o propósito de descrever como membros de organizações respondem aos eventos de ameaça à identidade que representam "um dilema simbólico e de sensemaking para os membros da organização". Os autores adotaram em sua pesquisa o conceito de IO percebida e identidade externa concebida (DUTTON, DUKERICH e HARQUAIL, 1994). O corpus analisado foi a classificação da revista Business Week dos vinte melhores cursos de MBA dos Estados Unidos.

Hatch e Schultz (2002) defendem a tese de que a dinâmica da identidade é mediada pela relação entre cultura e imagem. Por causa do inter-relacionamento recíproco entre identidade e imagem, a IO em vez de ser considerada duradoura é "relativamente fluida e adaptativamente instável", sendo sua durabilidade algo ilusório (GIOIA, SCHULTZ e CORLEY, 2000, p. 63).

Diante da necessidade de novos modelos organizacionais que se imponham num contexto de quebra de fronteiras e crescente virtualização, Caldas e Wood Jr. (1997) questionam a noção de IO como atributos centrais, distintivos e duradouros. Inicialmente, os autores construíram um modelo conceitual de dois eixos: dimensão do objeto focal de estudo (indivíduo, grupo, organização e humanidade) e dimensão da observação fenômeno (perspectiva interna ou externa de observação); posteriormente, um novo eixo foi proposto, dotando o quadro conceitual de uma dimensão epistemológica e ontológica da definição de identidade. Nessa dimensão, desafiam-se os atributos citados anteriormente, e defendem-se seus respectivos opostos: o caráter fragmentado, não distintivo e efêmero da identidade.

De um lado, a criação e a manutenção de uma identidade aparentemente duradoura são essenciais para o sucesso de longo prazo de uma organização (ALBERT e WHETTEN, 1985). De outro, as organizações precisam ter habilidade para se adaptar rapidamente a um ambiente cada vez mais turbulento, como condição essencial para o seu bem-estar e sua sobrevivência (BROWN e EISENHARDT, 1997). Por meio do conceito de "instabilidade adaptativa", Gioia, Schultz e Corley (2000) defendem a possibilidade de conviver com esse paradoxo, uma vez que as organizações podem fazer mudanças a despeito das ameaças subentendidas da pretensa natureza duradoura da identidade.

Scott e Lane (2000) também questionam as características de IO definidas por Albert e Whetten e introduzem um aspecto negocial entre as partes interessadas. Nesse sentido, a IO é descrita como um conjunto de crenças compartilhadas sobre características consideradas centrais, duradouras e distintivas da organização (ALBERT e WHETTEN, 1985), resultante de interações complexas, dinâmicas e recíprocas entre gestores, membros organizacionais e stakeholders. Entendem que o questionamento acerca da durabilidade versus dinâmica é exagerado, e defendem que a "IO precisa, certamente, adaptar-se às mudanças ambientais, mas, na realidade, a organização faz isso imperfeitamente. Não é nem estática nem fluida, mas inerentemente aderente" (SCOTT e LANE, 2000, p. 143). A mudança de identidade e sua durabilidade, assim, são respostas adaptativas às necessidades e demandas de audiências salientes da organização (stakeholders), ao longo de sua existência. A identidade é negociada e até haver concordância sobre seu conteúdo e estrutura os participantes na construção da IO (stakeholders) negociam a imagem da organização. Uma vez negociada, essa identidade dura até uma ou ambas as partes sinalizarem insatisfação 
com sua definição corrente. Logo, pode-se concluir que a IO, estável ou duradoura, é uma função da durabilidade do relacionamento entre organização/stakeholders, sendo essas interações complexas e dinâmicas (SCOTT e LANE, 2000).

Novas perspectivas de organizações têm evidenciado cada vez mais a fluidez de objetos organizacionais, como sua identidade e estrutura organizacional (GHADIRI e DAVEL, 2006). Esses autores propõem uma perspectiva proximal, em que a identidade nas organizações possa ser compreendida como um processo fluido, resultado "pontual, parcial, contextual e temporário de um contínuo processo de reconstrução" (GHADIRI e DAVEL, 2006, p. 5), razão pela qual a identidade não poderá ser imutável.

A título de síntese, os estudos de $I O$ apresentam três focos majoritários: voltados à criação e à formação da IO; à construção da IO e da mudança da IO (GIOIA, PRICE, HAMILTON et al., 2010), com uso de diversas metodologias. Como visto em diferentes abordagens, a 10 é um fenômeno em evolução teórica, envolvendo uma discussão entre identidade e pluralidade, um debate entre durabilidade e instabilidade, permanecendo a distintividade um atributo comum entre os estudiosos de IO. Essas múltiplas visões trazem um desafio à pesquisa de IO: refletir acerca de proposições metodológicas que concorram ao avanço teórico dos estudos de identidade.

A fim de conhecer as principais técnicas de análise usadas nas pesquisas brasileiras sobre IO fez--se uma busca no sistema SPELL com o termo "identidade organizacional" (título e palavras-chave) e na base SciELO. No SPELL, um total de 10 artigos foram publicados em periódicos entre 1997 (primeiro artigo publicado no tema IO) e 2015. Desse total, 7 artigos são teórico-empíricos, sendo que 5 adotaram a análise categorial temática (FERNANDES, MARQUES e CARRIERI, 2009; NOGUEIRA, 2007; MACHADO, 2005; MACHADO-DA-SILVA e NOGUEIRA, 2001; ÉSTHER, 2014), 1 artigo teve como base um estudo etnográfico (CAVEDON e STEFANOWSKI, 2008) e outro artigo se baseou em dados secundários (BORGES e MEDEIROS, 2011). Dois artigos são ensaios teóricos e um caracteriza-se como estudo bibliográfico. Na base SciELO, mais 4 artigos teórico-empíricos foram localizados. Bunchaft e Gondin (2004) utilizaram grupo de foco e análise de conteúdo, enquanto Rocha e Silva (2007) contemplaram a análise de conteúdo. Outras 2 pesquisas basearam-se na análise do discurso na linha francesa (SOUZA e CARRIERI, 2013; SOUZA, CARRIERI e FARIA, 2008).

Ravasi e Canato (2013) revisaram as metodologias empregadas em estudos internacionais teórico-empíricos no tema IO publicados em revistas acadêmicas de alto impacto (por exemplo, Academy of Management Journal, Administrative Science Quarterly, British Journal of Management, Human Relations, Journal of Management Studies, Organization Science, Organization Studies) entre 1985 e 2011. Os autores examinaram 33 artigos, dos quais 5 adotaram o método quantitativo. A construção da teoria fundamentada (17 artigos) foi com frequência empregada por acadêmicos interessados em pesquisar a relação entre 10 e outros constructos organizacionais, como cultura e imagem. Outro método qualitativo usado pelos pesquisadores de 10 foram múltiplas versões da etnografia (quatro). Três estudos não explicitaram claramente o tipo de análise qualitativa empregado. Diversos estudos abordaram a IO de uma perspectiva narrativa (cinco). Esses estudos adotaram uma ontologia construcionista social, sustentando que a realidade social é constituída por meio da linguagem e do discurso. Nenhum desses estudos declarou explicitamente o uso exclusivo de análise do discurso. Entretanto, Ravasi e Canato (2013) consideram que a aplicação de técnicas de linguística e análise do discurso parecem ser uma possibilidade promissora para ampliar a compreensão de como a IO é discursivamente representada por meio de linguagem e conversações. Essa posição se justifica pelo fato que a identidade no trabalho ocorre em contextos social e discursivo (SVENINGSSON e ALVESSON, 2003). As identidades organizacionais podem ser pensadas como identidades discursivas, sendo que as organizações constroem suas identidades por meio de estratégias discursivas (CHARAUDEAU, 2009).

\section{IDENTIDADE, DISCURSO E SEMIÓTICA}

Na visão de Charaudeau (2009), a identidade discursiva se constrói com base nos modos de tomada da palavra, na organização enunciativa do discurso e na manipulação dos imaginários sociodiscursivos. A identidade discursiva é sempre algo "a construir em construção" e necessita de uma base de identidade social; portanto, para Charaudeau (2009, p. 5) o discurso não é apenas linguagem, sua significação depende também da identidade social de quem fala. Por essa lógica, diferentes discursos podem coexistir em uma organização, contemplando múltiplas identidades. 
A identidade discursiva tem a particularidade de ser construída pelo sujeito falante para responder à questão: "Estou aqui para falar como?". Isso depende de um duplo espaço de estratégias: de "credibilidade" e de "captação" (CHARAUDEAU, 2009, p. 4). A credibilidade está ligada à necessidade, para o sujeito falante, de que se acredite nele, tanto no valor de verdade de suas asserções quanto no que ele pensa realmente, ou seja, em sua sinceridade. O sujeito falante deve, pois, defender uma imagem de si mesmo que lhe permita, estrategicamente, responder à questão: "Como fazer para ser levado a sério?" (CHARAUDEAU, 2009, p. 4). As estratégias de captação surgem quando o Eu-falante não está, para com seu interlocutor, numa relação de autoridade. Se estivesse, seria suficiente dar uma ordem para que o outro a cumprisse. A captação vem da necessidade, para o sujeito, de assegurar-se de que seu parceiro na troca comunicativa percebe seu projeto de intencionalidade, isto é, compartilha de suas ideais, suas opiniões e/ou está "impressionado" (tocado em sua afetividade). Deve, então, responder à questão: “Como fazer para que o outro possa 'ser tomado' pelo que digo". Nesse caso, o objetivo do sujeito falante passa a ser o de "fazer crer", para que o interlocutor se coloque numa posição de "dever crer". Será necessário tentar persuadir (fazer pensar recorrendo à razão) ou seduzir (fazer sentir recorrendo à emoção) o outro que, então, deverá pensar ou sentir o que foi significado (CHARAUDEAU, 2009).

Neste artigo, compreende-se a identidade discursiva no sentido de identidade construída pelo discurso, pelos atos da linguagem. Nesse caso pode ser tanto a identidade do indivíduo quanto a da organização, pois ambas são construídas pelas mesmas relações discursivas de identidade e alteridade. Discurso sendo entendido, em sentido amplo, ou seja, o termo contempla tanto o texto verbal (falado e escrito) quanto um conjunto de práticas (gestuais, visuais etc.).

Na discussão sobre os níveis de análise de identidade, Gioia (1998, p. 19) comenta que o trabalho de Tajfel (1982), na psicologia social, provê uma justificativa de que os "constructos de identidade possuem uma aparente robustez entre eles e sugere uma boa base para construir pontes da conceptualização da identidade individual para a organizacional", diferindo sobretudo em seu caráter coletivamente compartilhado. Nessa mesma linha, alguns autores defendem que a identidade individual e a organizacional são mútua e reciprocamente ligadas (BROWN, 1997; ELSBACH e KRAMER, 1996).

A articulação entre identidade e semiótica aparecem intrinsecamente ligadas na teoria semiótica de Greimas. A semiótica textual de Greimas pode ser aplicada à análise da ação organizacional (ROBICHAUD, 2002; BENCHERKI e COOREN, 2011). Robichaud (2002) mostra que as estruturas narrativas podem ser encontradas na estrutura das atividades organizacionais, como evidenciou em pesquisa de campo feita em uma administração municipal canadense.

Na mesma linha de raciocínio, Bencherki e Cooren (2011) argumentam que o modelo greimasiano de narratologia é uma teoria de ação, e não apenas uma ferramenta analítica para interpretar narrativas. Os autores defendem que a narratologia de Greimas permite ver os programas de ação e suas incorporações e seus embricamentos através da lente narrativa. Nesse processo o "sensemaking é o coração da abordagem: [...] não é apenas uma construção dentro da mente do indivíduo, [...] é também uma construção muito 'real' de um mundo significativo e produtor de sentido" (BENCHERKI e COOREN, 2011, p. 1592). Se as pessoas agem de acordo com sua identificação com o grupo a que pertencem, na ótica da teoria da identidade social (ASHFORTH e MAEL, 1989), então a criação de sentido (sensemaking), central na teoria de ação, permite conectar-se com a questão da IO: fazer sentido do que aconteceu, que está acontecendo ou pode acontecer não é apenas uma questão de entendimento, mas também uma forma pela qual os participantes reconfiguram sua organização (BENCHERKI e COOREN, 2011).

\section{A SEMIÓTICA DO DISCURSO}

A teoria semiótica foi desenvolvida por A. J. Greimas e pelo Grupo de Investigações Sêmio-Linguísticas da Escola de Altos Estudos em Ciências Sociais (Paris, França).

Como teoria da língua e da linguagem, a linguística, por algum tempo, não ultrapassava os limites da frase como unidade linguística e deixava de lado outras questões referentes ao estudo da língua, como seu uso e suas relações com o contexto social e histórico. A teoria semiótica concebe o texto como unidade de sentido e não mais a frase, ou, ainda, como ressaltado por Barros (1997, p. 7), considera que "o sentido da frase depende do sentido do texto". À vista disso, a semiótica, tendo por objeto o texto, busca "descrever e explicar o que o texto diz e como ele faz para dizer o que diz". 
A semiótica, como teoria da significação, preocupa-se em primeira instância, com as condições de "apreensão e produção do sentido" levando em conta a "criação ou apreensão das diferenças, que são necessárias para se estabelecer a estrutura elementar da significação" (GREIMAS e COURTÉS, 2011, p. 455).

Em seu estágio estrutural, a semântica de Greimas (1976) propõe que a significação manifestada por meio de discurso, resulta na visão de mundo por meio da qual as coisas são lidas ganhando uma existência dita semiótica. Dessa forma, estudar o processo de significação é o mesmo que estudar como o mundo adquire sentido, complementa Pietroforte (2008).

O sentido na forma de texto pode ser considerado de três orientações teóricas: como criação em seu processo genético; como rede de relações em sua construção formal; e em processos interpretativos, tomando-o "como conteúdos manifestos de estruturas latentes diferentes dele", complementa Pietroforte (2008, p. 10). A semiótica considera a segunda concepção teórica e visa, portanto, ao estabelecimento das "regularidades formais capazes de determinar as articulações sintáticas e semânticas que dão forma ao sentido", como uma rede dessas relações (PIETROFORTE, 2008, p. 11).

O texto para a semiótica é a relação entre o plano de conteúdo semântico e o plano de expressão em que se manifesta, quando então o sentido se realiza em textos. O discurso é uma unidade do plano de conteúdo, é o nível em que as formas "abstratas são revestidas de concretude" (FIORIN, 2011, p. 45). Tanto nos discursos de natureza religiosa, científica, jurídica, política etc. quanto em textos verbais, musicais, plásticos etc., há sempre uma geração de sentido, há espaço teórico nesses fazeres humanos para os modelos da semiótica (PIETROFORTE, 2008).

A teoria semiótica, como expresso por Barros (1997), deve determinar inicialmente o que é o texto e qual é seu objeto de estudo. Segundo a autora, o texto é concebido como objeto de significação dotado de procedimentos e mecanismos estruturais que Ihe conferem o todo de sentido. Esses procedimentos são objeto de análise interna ou estrutural do texto. $O$ texto tem uma organização interna que produz sentido, mas também circula em um dado momento e lugar entre sujeitos, sendo, portanto, histórico, social e cultural (BARROS, 2012).

Dessa forma, de maneira complementar ao objeto de significação, o texto pode ser concebido como objeto de comunicação entre dois sujeitos. Assim, o texto é também entendido como objeto social e cultural "determinado por formações ideológicas específicas" e necessita ser analisado em seu contexto sócio-histórico que lhe confere sentido, por meio das relações intertextuais e interdiscursivas (BARROS, 1997, p. 7). Nessa concepção de texto, a semiótica examina os procedimentos, os métodos e as técnicas da sua organização, bem como os mecanismos enunciativos de produção e recepção do texto para explicar os processos de significação (BARROS, 1997).

Assim sendo, a semiótica como teoria geral do texto objetiva explicar os sentidos do texto. Para tal, faz metodologicamente a abstração do plano de expressão, examinando em primeiro lugar só o plano de conteúdo.

\section{PERCURSO GERATIVO DE SENTIDO}

Para examinar o plano do conteúdo, Greimas (1976) propõe, metodologicamente, que esse exame se faça em um percurso que parta do mais abstrato e mais simples para o mais complexo e concreto, o que é denominado de percurso gerativo de sentido.

O sentido do texto se constrói, na visão semiótica, por meio de seu plano de conteúdo na forma do percurso gerativo de sentido. O percurso gerativo de sentido "é um modelo que simula a produção e interpretação do significado, do conteúdo", como define FIORIN (2011, p. 44). Esse percurso é decorrente de uma sucessão de níveis, "que mostra como se produz e se interpreta o sentido, num processo que vai do mais simples ao mais complexo" (FIORIN, 2011, p. 44).

O modelo teórico greimasiano apresenta o percurso gerativo de sentido formado por três níveis ou etapas.

O primeiro nível de geração de sentido denomina-se "fundamental" e nele a semiótica define a categoria semântica que dá conta de organizar a totalidade do discurso. Nesse nível se estabelece uma estrutura elementar em que a rede de relação da narrativa do texto se reduz a uma única relação por diferença ou oposição (BARROS, 1997). É necessário que nessa relação haja algo em comum entre seus termos e que se estabeleça uma diferença, por uma relação de contrariedade (FIORIN, 2011). Tal ligação é de diferença ou oposição "entre dois termos dos conteúdos fundamentais das relações estruturadas em 
um mesmo eixo semântico" do texto e é representada por um modelo denominado "quadrado semiótico" (BARROS, 1997, p. 77-78), como apresentado e esquematizado na Figura 1.

\section{Figura 1}

\section{Quadrado Semiótico}

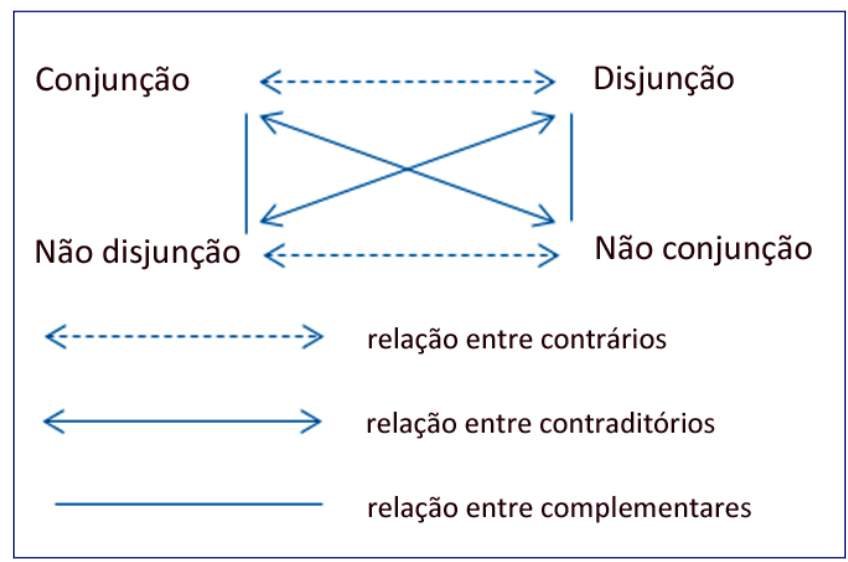

Fonte: Barros (1997, p. 78).

O quadrado semiótico é definido como uma representação da "articulação lógica de uma categoria semântica qualquer", ou seja, de uma estrutura elementar da significação definida como relação entre dois termos e que se apoia "sobre uma distinção de oposição" (GREIMAS e COURTÉS, 2011, p. 400).

Essa estrutura elementar, de natureza binária, é reconhecida com base em dois tipos de relações, uma definida pelas oposições ou contrariedade (ausência ou presença de um traço definido) e a outra pela não ausência e não presença que estabelecem com os termos originais relações que negam ou relações contraditórias, e entre os termos originais respectivos e as negações contrárias, uma relação de complementaridade.

A categoria, portanto, trabalha com termos opostos, a exemplo de opressão e liberdade, morte e vida, natureza e cultura. O sentido se organiza em redes de relações semióticas em que cada um desses termos encontra sua definição em relação ao outro termo oposto (PIETROFORTE, 2008). Os elementos da categoria semântica do nível fundamental na base do texto recebem uma qualificação eufórica quando considerados referentes a valores positivos e são qualificados de forma disfórica quando são vistos "como um valor negativo" (FIORIN, 1999, p. 21). A orientação dessas relações entre os termos de oposição é a primeira condição para a narratividade, uma vez que as estruturas fundamentais transformam-se em estruturas narrativas e essas se transformam em discurso. Por meio da categoria semântica do nível fundamental é que se dá "sentido ao conjunto de elementos do nível superficial" (FIORIN, 2011, p. 21).

O segundo nível de geração de sentido é o "narrativo", em que o sujeito narrador apresenta a "história" do texto. A narratividade se refere a uma "transformação entre dois estados sucessivos e diferentes", em que há, portanto, uma narrativa mínima: "um estado inicial, uma transformação e um estado final”, complementa Fiorin (2011, p. 28). Nesse nível, uma rede de relações constitui-se com o objeto de valor para estabelecer o estado de junção das coisas (conjunção ou disjunção) e o sujeito narrativo pode afirmar ou negar a conjunção ou a disjunção com esse objeto de valor.

O terceiro nível é o "discursivo" em que a sintaxe e a semântica promovem a significação ao discurso por meio da conversão dos actantes (elementos presentes no ato de comunicação, participantes ativos ou passivos do predicado) do nível narrativo em atores, atuando em um espaço e tempo determinados. Nesse nível há a especificação dos papéis temáticos, além de conotações sociais, por meio de objetos de valor, investidos nos sujeitos discursivos. Os procedimentos semânticos desse nível são a tematização e a figurativização. Essa busca dar concretude e efeito de realidade aos temas abstratos do discurso. 
Na semiótica greimasiana, em cada nível são analisados seus mecanismos sintáxicos e semânticos. A sintaxe examina as regras referentes às relações entre os vocábulos, "à construção das orações e às relações interacionais [...], como um conjunto de regras que rege o encadeamento das formas de conteúdo do discurso" (FIORIN, 2011, p. 20) e que pode receber diversos investimentos semânticos. Cada combinação de formas pode produzir um determinado sentido. A Figura 2 ilustra os níveis do percurso gerativo de sentido.

Figura 2

Percurso gerativo de sentido

\begin{tabular}{|c|c|c|c|}
\hline \multicolumn{2}{|c|}{} & $\begin{array}{c}\text { Componente } \\
\text { Sintáxico }\end{array}$ & $\begin{array}{c}\text { Componente } \\
\text { Semântico }\end{array}$ \\
\hline \multirow{2}{*}{$\begin{array}{c}\text { Estruturas } \\
\text { narrativas }\end{array}$} & Nível & $\begin{array}{c}\text { Sintaxe } \\
\text { fundamental }\end{array}$ & $\begin{array}{c}\text { Semântica } \\
\text { fundamental }\end{array}$ \\
\cline { 2 - 4 } & Nível de & Sintaxe & Semântica \\
superfície & narrativa & narrativa \\
\hline \multirow{2}{*}{$\begin{array}{c}\text { Estruturas } \\
\text { discursivas }\end{array}$} & $\begin{array}{c}\text { Sintaxe discursiva Discursivização } \\
\text { (actorialização, temporalização, }\end{array}$ & $\begin{array}{c}\text { Semântica } \\
\text { discursiva } \\
\text { Tematização } \\
\text { espacialização) }\end{array}$ & $\begin{array}{c}\text { Figurativização } \\
\end{array}$ \\
\multicolumn{2}{|c}{} & \\
\hline
\end{tabular}

Fonte: Fiorin (2011, p. 20).

\section{SINTAXE E SEMÂNTICA NARRATIVA}

Na sintaxe narrativa a história se apresenta com seus personagens e seus papéis, e com as transformações do sujeito ou sujeitos que agem em busca dos valores investidos nos objetos e promovem, dessa forma, mudanças do estado das coisas. Outros aspectos presentes nessa sintaxe são os contratos estabelecidos entre um sujeito destinador e um destinatário por meio de sucessivos estabelecimentos e rupturas desse contrato (BARROS, 1997).

A sintaxe narrativa tem dois tipos de enunciados: o de estado e o de fazer. É nos enunciados de estado que se estabelece a relação de junção, podendo ser de conjunção ou disjunção nas relações transitivas entre sujeito e objeto de valor, ao passo que no enunciado de fazer, apresentam-se as transformações (FIORIN, 2011) empreendidas pelo sujeito, relacionando sujeito e objeto.

A hierarquia entre os enunciados de fazer e de estado define um "programa narrativo" como unidade "elementar na organização narrativa de um texto" (BARROS, 1997, p. 20). Um texto é uma narrativa complexa que envolve uma série de enunciados de estado (ser) e enunciados de fazer de forma hierárquica, organizados em uma sequência canônica que envolve as fases de: competência, perfórmance, manipulação e sanção (FIORIN, 2011).

Para Barros (1997), o programa narrativo define dois tipos fundamentais de programas: o programa de competência e o programa de perfórmance. 
A competência se estabelece pela doação de valores modais ao sujeito, capacitando-o para agir, e, pela perfórmance, esse sujeito age e produz ou se apropria dos objetos de valor desejados. Há, portanto, dois tipos de perfórmances: a de aquisição e a de produção dos objetos investidos dos valores desejados pelo sujeito.

Ao conjunto de programas de competência e de perfórmance relacionados por pressuposição se denomina um percurso narrativo. O percurso do sujeito é um dos percursos narrativos possíveis. Nele ocorre o programa de aquisição da competência necessária para agir e executar uma perfórmance e a realização dessa perfórmance (BARROS, 1997).

Na organização narrativa, há dois outros tipos de percurso: o do destinador- manipulador e o do destinador-julgador. No percurso do destinador-manipulador o sujeito passa a ser um doador ou destinador dos valores modais. "O destinador muda o sujeito pelas suas determinações modais" e semânticas e, dessa forma, "faz-fazer, representando uma ação do homem sobre o homem", pontua Barros (1997, p. 28).

Para que o destinador-manipulador doe a competência modal, é necessário que o destinatário sujeito compartilhe do mesmo sistema de valores do destinador. Assim o destinador-manipulador efetivamente doa os valores modais do querer-fazer, do dever-fazer, do saber fazer e do poder fazer.

Em sua manipulação o destinador propõe um contrato ao destinatário valendo-se de um fazer-persuasivo. Em contraponto, há um fazer interpretativo do destinatário que pode assim aceitar ou rejeitar esse contrato. Para tal, o sujeito destinador que sabe e pode se vale de quatro tipos de estratégias de manipulação em relação ao sujeito-destinatário: a tentação, a intimidação, a provocação e a sedução.

A tentação se dá quando o destinador-manipulador propõe um objeto de valor positivo como recompensa visando a levar o destinatário a fazer algo. É por meio da intimidação que o destinador ameaça o destinatário, obrigando-o a fazer alguma coisa. A provocação usa a estratégia de o destinador-manipulador apresentar um juízo negativo da competência do destinatário, levando-se a fazer algo para afastar essa imagem negativa. A sedução ocorre quando o destinador leva o destinatário a fazer algo "manifestando um juízo positivo sobre (sua) competência", considera Fiorin (2011, p. 30).

O terceiro percurso narrativo é o do destinador-julgador, que sancionará o sujeito- destinatário "pela verificação de suas ações e dos valores com que se relaciona" por meio da interpretação dos estados resultantes do seu fazer (BARROS, 1997, p. 29). Esses estados podem ser verdadeiros ou que parecem e são, podem ser falsos ou que parecem, mas não são, podem ser secretos ou que não parecem, mas são ou ainda mentirosos ou que parecem, mas não são.

O destinador-julgador, com base na conduta do sujeito com seu sistema de valores e com os valores do contrato estabelecido entre ambos, julga se o sujeito cumpriu o compromisso assumido durante a manipulação. Essa interpretação se faz "em nome de uma ideologia que depende do sentido do percurso narrativo realizado" (BARROS, 1997, p. 29). O percurso narrativo do destinador-julgador se dá pela sanção positiva por meio do reconhecimento e da recompensa ou de sua sanção negativa por meio do desmascaramento e da punição. Nessa fase ocorre, portanto, a confirmação de que a perfórmance aconteceu e há o reconhecimento de que o sujeito efetivamente realizou ou não a transformação.

Ainda no nível narrativo do percurso gerativo de sentido, devem ser analisados os aspectos semânticos, ou seja, a semântica narrativa. A semântica narrativa consiste no "momento em que os elementos semânticos são selecionados e relacionados com os sujeitos" e esses elementos são inscritos como "valores nos objetos no interior dos enunciados de estado" (BARROS, 1997, p. 41). Na narrativa aparecem dois tipos de valores inseridos nos objetos: os modais, que se referem ao querer, dever, saber e poder fazer necessários para realizar a perfórmance; e os descritivos com os quais se entra em conjunção ou disjunção, graças a perfórmance.

A modalização do ser que instaura o sujeito considera dispositivos modais que produzem os efeitos de sentido ditos afetivos ou passionais, como medo, amor e desejo. Na semiótica esses efeitos de sentido das qualificações modais alteram o sujeito de estado.

Em uma narrativa o sujeito pode ocupar diferentes posições passionais alternando estados de tensão e estados de relaxamento, ou ainda estados de disforia e estados de euforia e vice-versa (BARROS, 1997). Além da modalização do ser, deve-se considerar também a modalização do fazer, que dá competência modal ao sujeito qualificando-o para a ação. A modalização 
do fazer leva em conta dois aspectos, o primeiro refere-se ao fazer-fazer, quando o destinador comunica ao sujeito-destinatário os valores modais para que esse faça, e o outro aspecto se refere ao ser-fazer que considera a "organização modal da competência do sujeito", como apontado por Barros (1997, p. 43).

A Figura 3 ilustra o nível narrativo do percurso narrativo de sentido.

Figura 3

Percurso gerativo do sentido: nível narrativo

\begin{tabular}{|c|c|c|c|}
\hline \multirow{7}{*}{$\begin{array}{l}\text { Sintaxe } \\
\text { narrativa }\end{array}$} & \multicolumn{3}{|c|}{ Enunciado } \\
\hline & Estado (ser) & & Fazer \\
\hline & \multicolumn{3}{|c|}{ Programa Narrativo (PrN) } \\
\hline & $\begin{array}{l}\text { Programa de competência } \\
\qquad(\operatorname{PrNC})\end{array}$ & \multicolumn{2}{|c|}{ Programa de perfórmance (PrNP) } \\
\hline & \multicolumn{3}{|c|}{ Percurso Narrativo (PeN) } \\
\hline & PeN do sujeito & $\begin{array}{l}\text { PeN do destinador/ } \\
\text { manipulador }\end{array}$ & PeN do destinador/julgador \\
\hline & $\begin{array}{l}\text { Sequência de } \\
\text { PrNC e PrNP }\end{array}$ & Manipulação & $\begin{array}{l}\text { Interpretação ou sanção cognitiva } \\
\text { Retribuição ou sanção pragmática }\end{array}$ \\
\hline \multirow{4}{*}{$\begin{array}{l}\text { Semântica } \\
\text { narrativa }\end{array}$} & \multicolumn{3}{|c|}{ Modalidade do Ser } \\
\hline & Jogo entre o ser e o parecer & \multicolumn{2}{|c|}{ Efeito de sentidos afetivos ou passionais } \\
\hline & \multicolumn{3}{|c|}{ Moderação do fazer } \\
\hline & Fazer-Fazer & & Ser-Fazer \\
\hline
\end{tabular}

Fonte: Elaborada pelos autores.

Em relação aos contratos de confiança estabelecidos entre os sujeitos esses não são necessariamente contratos "reais", mas contratos imaginários, simulacros. Citando Greimas, Barros (1997, p. 50) reitera que esses "simulacros não têm fundamento intersubjetivo, embora determinem, mesmo assim, as relações entre os sujeitos".

\section{SINTAXE E SEMÂNTICA DISCURSIVA}

O terceiro nível do percurso gerativo de sentido da semiótica greimasiana é o discursivo que se refere ao nível mais superficial do percurso, o mais específico, complexo e rico semanticamente. Enquanto no nível narrativo estão formas abstratas com que o sujeito entra em conjunção, é no nível discursivo que essas formas abstratas se desenvolvem como temas e se revestem "de termos que lhes dão concretude", por exemplo, no caso do tema como riqueza, o recebimento de uma herança, de um prêmio de loteria etc. (FIORIN, 2011, p. 41). 
As organizações discursivas, da mesma forma que as narrativas, são explicadas por meio de seus aspectos sintáxicos e semânticos. No aspecto sintáxico do nível discursivo, Barros (1997, p. 53) ressalta que "as estruturas narrativas convertem-se em estruturas discursivas quando assumidas pelo sujeito da enunciação" que faz escolhas de pessoa, de espaço, de tempo, enriquece e "'conta' ou passa a narrativa, transformando-a em discurso". Por meio dessas escolhas, o sujeito da enunciação se relaciona, portanto, com o discurso que enuncia.

A enunciação como mediação entre as estruturas narrativas e discursivas pode ser construída a partir das "marcas" deixadas no discurso. É nas estruturas discursivas que a enunciação mais se revela e que se reconhecem os valores sobre os quais se construiu o texto e também sob que condições esse se desenvolveu. Assim, a sintaxe do texto explica as relações entre o sujeito da enunciação e o discurso enunciado e as relações estabelecidas em torno de um enunciador e um enunciatário. Em outras palavras, o discurso é um objeto de significação produzido pelo sujeito da enunciação, e de comunicação entre um destinador e um destinatário (BARROS, 1997).

É na produção do discurso que o sujeito da enunciação se vale de meios de persuasão "para convencer o enunciatário da 'verdade' de seu texto", enfatiza Barros (1997, p. 54). Ao projetar seu discurso, o sujeito da enunciação faz opções para produzir efeitos de sentido e se vale para isso de mecanismos discursivos, buscando persuadir o destinatário de que seu discurso é verdadeiro ou falso, criando uma "ilusão de verdade" (BARROS, 1997, p. 55).

Nesse sentido, o sujeito da enunciação adota mecanismos que produzem dois efeitos de sentido: o efeito de proximidade ou distanciamento e o de realidade ou referente. $O$ efeito de proximidade ou distanciamento em relação à enunciação pode ser notado, por exemplo, em notícias de jornal que produzem discursos na terceira pessoa no tempo "então" e no espaço "lá", visando a uma ilusão de distanciamento da enunciação e proporcionando efeito de objetividade; e, sobretudo, de imparcialidade por parte do jornal em relação ao seu enunciado. O mecanismo é denominado desembreagem ou debreagem enunciva para a terceira pessoa ou como desembreagem ou debreagem enunciativa para a primeira pessoa, a fim de produzir efeitos de proximidade e subjetividade no discurso. A desembreagem enunciva ou a enunciativa desdobram-se cada qual em desembreagem de pessoa, espaço e tempo. Na literatura da semiótica do discurso, as palavras desembreagem e debreagem são usadas com o mesmo significado.

Esses procedimentos produzem, na desembreagem enunciativa, efeitos de enunciação, em que o narrador é o "delegado da enunciação em primeira pessoa" e o "sujeito da enunciação atribui ao narrador a voz" (BARROS, 1997, p. 56), conferindo-lhe o poder de, em seu lugar, narrar o discurso. O narrador também pode delegar internamente voz a outros interlocutores para atribuir a esses a responsabilidade discursiva. Por exemplo, os jornais muitas vezes "põem palavras na boca" de suas personagens desenvolvendo essa ilusão de transferência de responsabilidade do discurso.

Essa delegação de voz interna, chamada desembreagem interna, também é usada para dar efeitos de realidade ou de referente. As desembreagens ou debreagens internas são responsáveis "pela produção de simulacros de diálogos nos textos, pois estabelecem interlocutores, ao dar voz aos atores já inscritos nos discursos" (FIORIN, 2011) e, na forma de discurso direto, proporcionam ao enunciatário a ilusão de estar ouvindo o outro nas suas "verdadeiras" palavras, criando assim um efeito de realidade.

A enunciação é definida por Fiorin (1999, p. 36) como "a instância constitutiva do enunciado", pressuposta de forma lógica pela existência do enunciado comportando seus traços e marcas. O enunciado, por sua vez, é "toda grandeza dotada de sentido, pertencente à cadeia falada ou texto escrito", e resultante do ato da linguagem, independentemente de suas dimensões sintagmáticas (frase ou discurso) (GREIMAS e COURTÉS, 2011, p. 168).

Para Greimas e Courtés (2011, p. 166) o enunciado é "o resultado alcançado pela enunciação como instância de mediação, que assegura a colocação no enunciado-discurso das virtualidades da língua". A enunciação é concebida como uma instância de mediação que produz o discurso e que possibilita a passagem entre a competência e a perfórmance. A enunciação é a instância em que se instaura o sujeito (da enunciação). A "enunciação é um enunciado cuja função-predicado é denominada 'intencionalidade' cujo objeto é o enunciado-discurso" (GREIMAS e COURTÉS, 2011, p. 168).

O destinador implícito de uma enunciação é denominado enunciador, distintamente do narrador, que é um actante instalado no discurso. Da mesma forma, o destinatário implícito da enunciação é chamado de enunciatário. $O$ enunciatário não é só o destinatário do discurso, mas também sujeito da enunciação, da mesma forma que o enunciador (GREIMAS e COURTÉS, 2011). 
Nas projeções da enunciação, faz-se necessário verificar os mecanismos usados e os efeitos do sentido do discurso. Para tal, nos estudos dessas projeções se deve analisar o texto de forma ampla, incluindo-se as razões das escolhas dos mecanismos e seus decorrentes efeitos, considerando-se ainda as relações entre os elementos internos e externos responsáveis pela elaboração e realização dos discursos. Dessa forma, "o exame das relações entre os efeitos e mecanismos é uma das etapas da construção dos sentidos do texto, de seus fins e de suas 'verdades'”, afirma Barros (1997, p. 62). Além disso, deve-se examinar o contexto sócio-histórico e a formação ideológica que circunscreve o texto (BARROS, 1997).

É nas estruturas discursivas, conforme Barros (1997), que são mais reveladoras as relações enunciador-enunciatário, os meios de persuasão e a interpretação respectiva e que se dão por meio de um contrato entre ambos. No jogo de persuasão envolvendo enunciador e enunciatário, o primeiro se vale de procedimentos argumentativos com o objetivo de convencer o segundo a aceitar como válido aquele sentido produzido pelo enunciatário (FIORIN, 2011). Assim, nessas relações contratuais, deve-se considerar a relativização sociocultural entre enunciador-enunciatário, os valores subjacentes no discurso e as crenças que lastreiam as interpretações do enunciatário. No encontro e no reconhecimento das marcas deixadas no discurso pelo enunciador e, após compará-las com suas convicções e conhecimentos, o enunciatário pode, então, crer ou não no discurso (BARROS, 1997).

Por esses motivos, o discurso constrói sua própria verdade, ou seja, os discursos produzidos não são verdadeiros ou falsos, mas parecem verdadeiros ou falsos, dependendo de como são interpretados. De outra forma, discursos mal feitos pelo enunciador poderão não ser ditos como verdadeiros mediante a interpretação do enunciatário. Ou ainda, dito como falsos ou mentirosos "quando um texto é inserido no contexto de outros textos e, a partir do confronto pode-se então recusá-lo" (BARROS, 1997, p. 64). No estudo dos textos deve-se, portanto, verificar os recursos empregados pelo enunciador para deixar no texto marcas de veridicção para que o enunciatário as reconheça.

Finalmente, como frisado por Fiorin (1999, p. 15) qualquer teoria do discurso considera que: "o discurso embora obedeça às coerções da estrutura é de ordem do acontecimento", ou seja, é de natureza histórica e que "não há acontecimento fora dos quadros do tempo, do espaço e da pessoa". Complementa o autor que "compreender os mecanismos da temporalização, espacialização e actorização é fundamental para entender o processo de discursivização" (FIORIN, 1999, p. 15).

No nível discursivo, a coerência semântica do discurso do sujeito da enunciação se dá por meio de percursos temáticos e figurativos. A semântica discursiva tem, então, dois procedimentos. O primeiro é a tematização, que ocorre pela formulação dos valores abstratos, organizando-os em percurso, pela recorrência de semas ou traços semânticos recorrentes no discurso. Os temas são de natureza conceitual, de forma abstrata e organizam, categorizam os elementos do mundo, como vaidade, vergonha, habilidoso, avarenta etc. (FIORIN, 2011).

O segundo procedimento da semântica discursiva se refere à figurativização, que busca, por meio de revestimentos figurativos ou ainda de figuras de conteúdo, trazidos pelo sujeito da enunciação, dar concretude aos discursos, "atribuindo-lhes traços de revestimento sensorial” (BARROS, 1997, p. 72). A figurativização produz a ilusão de realidade e referente. O crédito na "verdade" do discurso ocorre pelo reconhecimento por parte do enunciatário de "imagens ou figuras do mundo". A figura é, portanto, qualquer tipo de conteúdo de qualquer sistema de representação de qualquer língua que tem em correspondência algo ou algum elemento "perceptível no mundo natural" (FIORIN, 2011, p. 91).

A separação do discurso em sintaxe e semântica permite, de forma mais precisa, determinar as relações entre a linguagem e a ideologia (FIORIN, 1999). No nível sintático-discursivo, no qual se determinam os mecanismos de instauração pelo sujeito da enunciação das categorias de pessoa, espaço e tempo, não se esclarece a formação ideológica do discurso. É na semântica do discurso que podem ser encontrados os conteúdos ideológicos, em especial pelas figuras vinculadas a orientações temáticas, "e que a ideologia pode ser estudada com mais evidência", enfatiza Pietroforte (2008, p. 34).

Em semiótica, a ideologia se "caracteriza pelo estatuto atualizado dos valores que ela assume" por meio de um sujeito individual ou coletivo modalizado pelo querer-ser e pelo querer-fazer. Como procura permanente desse objeto de valor, a ideologia se esvanece quando o sujeito realiza os valores, com os quais mantinha conjunção.

A Figura 4 sintetiza o nível discursivo do percurso gerativo de sentido. 
Figura 4

Percurso gerativo do sentido: nível discursivo

\begin{tabular}{|c|c|c|}
\hline \multirow{6}{*}{$\begin{array}{l}\text { Sintaxe } \\
\text { discursiva }\end{array}$} & \multirow{2}{*}{\multicolumn{2}{|c|}{$\begin{array}{l}\text { Pessoa (Eu/ele) - Actoralização } \\
\text { Espaço (Aqui/lá) - Espacialização } \\
\text { Tempo (Agora/então) - Temporalização }\end{array}$}} \\
\hline & & \\
\hline & \multicolumn{2}{|c|}{ Efeito de proximidade ou distanciamento } \\
\hline & $\begin{array}{l}\text { Uso da 3a pessoa } \\
\text { Desembreagem enunciva } \\
\text { Efeito de sentido de objetividade }\end{array}$ & $\begin{array}{l}\text { Uso da 1a pessoa } \\
\text { Desembreagem enunciativa } \\
\text { Efeito de sentido da subjetividade }\end{array}$ \\
\hline & \multicolumn{2}{|c|}{ Efeito de realidade ou de referente } \\
\hline & $\begin{array}{l}\text { Na desembragem interna cede-se } \\
\text { a palavra aos interlocutores, em } \\
\text { discurso direto }\end{array}$ & $\begin{array}{l}\text { A ancoragem liga o discurso a } \\
\text { pessoas, espaços e datas que o } \\
\text { receptor conhece como "reais" }\end{array}$ \\
\hline $\begin{array}{l}\text { Semântica } \\
\text { discursiva }\end{array}$ & \multicolumn{2}{|c|}{$\begin{array}{l}\text { Tematização = os temas são de natureza conceitual e abstrata } \\
\text { Figurativização = dá concretude e sensorialidade ao discurso. Produz ilusão } \\
\text { de realidade e referente }\end{array}$} \\
\hline
\end{tabular}

Fonte: Elaborada pelos autores.

Esse tópico apresentou o percurso gerativo do sentido (Fig. 2) e suas três etapas: a fundamental (Fig. 1), a sintaxe e a semântica narrativa (Fig. 3) e a sintaxe e a semântica discursiva (Fig. 4). $O$ tópico a seguir explora como o conceito desse percurso gerativo se articula com o de 10 .

\section{UMA ARTICULAÇÃO ENTRE A ABORDAGEM SEMIÓTICA DO DISCURSO E A IO}

Esse tópico objetiva mostrar como os elementos da análise semiótica, em seu nível mais profundo e abstrato, contribuem para o tratamento do fenômeno da $\mathrm{IO}$ em uma abordagem dinâmica, fluida e tensional, devido à revelação de suas relações entre contrários, contraditórios e complementares.

A análise semiótica do texto se vale de regimes de interação que são definidos pelos modos de junção (conjunção-disjunção-não conjunção-não disjunção) ao sistema de valores e aos sujeitos do discurso, como um espaço teórico para o estudo das relações intersubjetivas por meio dos regimes de interação sociossemióticos propostos por Landowski (2002).

Essas trajetórias orientadas em torno dos sistemas de valores foram sistematizadas por Pietroforte, com base nos estudos de Landowski (2002) e Floch (1995), a partir da articulação dos termos identificação e diferenciação. Pietroforte (2008) desenvolveu um quadrado semiótico que inclui esses dois opostos fundamentais (identificação e diferenciação) e seus contraditórios ou complementares como a negação da identificação, que se dá na singularização, e a negação da diferenciação, que se dá na assimilação (Fig. 5).

Greimas e Courtés (2011) enfatizam a diferença entre a disjunção, que se refere a não ter mais alguma coisa, e a não conjunção, que significa não ter mais alguma coisa, e que muitas vezes tem características de transitoriedade e de estado tensional ao encaminhar-se na direção da disjunção. 
Os regimes de interação só "ganham sentido uns em relação aos outros", e o semioticista deve mostrar "como esta rede de relações está articulada" e a seguir "descrever os desdobramentos discursivos de cada regime" (PIETROFORTE, 2008, p. 94).

Conforme Greimas e Courtés (2011, p. 251), a identidade é um conceito, "não definível”, que se opõe "ao de alteridade", que também "não pode ser definido", mas, por uma relação de recíproca pressuposição, esse par é interdefinível e necessário para lastrear a estrutura elementar da significação em semiótica. A identidade determina um conjunto de traços que dois objetos ou mais têm em comum, de forma distinta da igualdade que "caracteriza objetos que têm exatamente as mesmas propriedades qualitativas" e encerra um princípio de permanência, em que o indivíduo permanece o mesmo, "persistindo no seu ser" ao longo de sua existência narrativa, mesmo depois das transformações realizadas ou sofridas, ou como ator discursivo no "discurso em que está inscrito" (GREIMAS e COURTÉS, 2011, p. 252). A articulação entre a identidade e a alteridade pode constituir a estrutura elementar da significação de certos textos, representada no quadrado semiótico já citado.

Nesse sentido, numa abordagem semiótica a IO é um conceito interdefinível, ou seja, compreender um atributo identitário de uma organização ocorre por meio do entendimento de seu oposto (alteridade), em uma relação de recíproca suposição. Dessa forma, configura-se a estrutura elementar do procedimento semiótico.

Nas relações termo a termo, a categoria formal da identidade versus alteridade, com base na proposta de Landowski (2002), estabelece os regimes de interação: o da identificação, pela afirmação da identidade, o da singularização, por sua negação, o da diferenciação, pela afirmação da alteridade, e o da assimilação, por sua negação, como no quadro semiótico proposto por Pietroforte (2008, p. 86), ilustrado na Figura 5.

\section{Figura 5}

\section{Quadrado Semiótico de Identificação-Diferenciação}

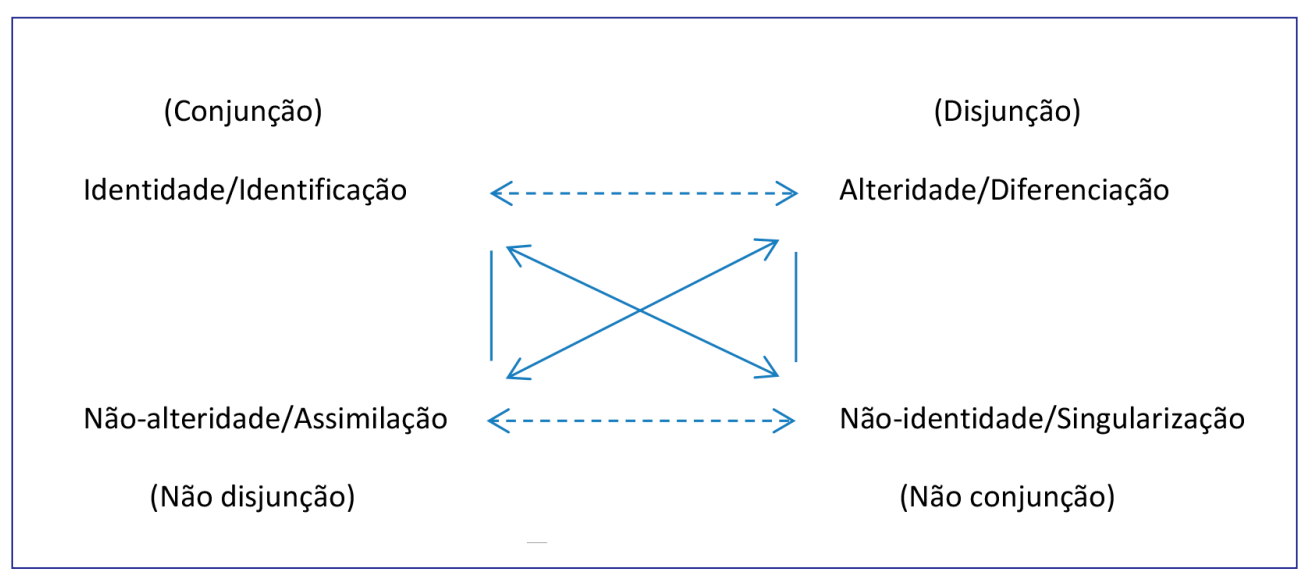

Fonte: Pietroforte (2008, p. 86).

As oposições como dia e noite, morte e vida, cultura e natureza se dão por relações que estão na base do procedimento semiótico, como reconhecimento de uma diferença de qualquer ordem que "permite constituir como unidades discretas e significantes as grandezas consideradas e associar a ela, não menos diferencialmente, certos valores" (LANDOWSKI, 2002, p. 3). Da mesma forma, passa-se pelo sujeito eu ou nós como uma grandeza que se constitui em termos de sua identidade, ou seja, só pode se constituir pela diferença em relação ao outro, para chegar a sua existência semiótica, pois o "sentimento de identidade passa necessariamente pela intermediação de uma alteridade”, complementa Landowski (2002, p. 4).

Da mesma maneira, as organizações mantêm sua identidade por meio de relações e interações com outras organizações mediante um processo de comparação interorganizacional ao longo do tempo (ALBERT, 1977). Por via dessas interações interorganizacionais e com indústrias, grupos competitivos e entidades sociais e econômicas, dá-se a identidade como um conceito relacional e comparativo, conforme defende a teoria da identidade social (TAJFEL e TURNER, 1986). 
Landowski (2002) batizou as oposições contraditórias de identidade e alteridade como segregação e agregação (admissão). Embora afirme haver certa arbitrariedade na escolha desses rótulos, o autor reitera que o que importa são as descrições estruturais de cada uma dessas configurações e a forma pela qual essas "se articulam ou se opõem para formar uma rede de diferenças inteligíveis" (LANDOWSKI, 2002, p. 15).

A agregação (não alteridade) parte do reconhecimento do outro apesar de sua diferença, ou seja, aceitando-o próximo, ao lado, como integrante de si, como no exemplo citado por Landowski (2002) da situação matrimonial que envolve a separação de corpos e em que, de forma transitória, não se passa ou para o estado de disjunção ou de suspensão completa dos vínculos do matrimônio (divórcio). Há um caráter possível de transitoriedade, instabilidade e tensão entre estados de junção opostos.

A segregação (não identidade) tem um sentido de separação ou marginalização como no exemplo de cunho político-social do apartheid. Não há desintegração das unidades, mas a separação de forma distinta das unidades.

Com base em Landowski (2002) e Pietroforte (2008), apresenta-se o quadrado semiótico de identidade-alteridade-agregação-segregação proposto na Figura 6.

Figura 6

\section{Quadrado Semiótico de Identidade e Alteridade}

\begin{tabular}{|l} 
(Conjunção) \\
Agregação \\
(Não disjunção)
\end{tabular}

Fonte: Adaptado de Landowski (2002) e Pietroforte (2008).

A análise da Figura 6 permite compreender que a IO, à luz da abordagem semiótica do discurso, é um conceito dinâmico, fluido, transitório e, nesse sentido, também múltiplo. Sendo a identidade interdefinível (GREIMAS e COURTÉS, 2011), sua construção é constantemente tensionada pelas relações de oposições demonstradas por meio do quadrado semiótico. O caráter de transitoriedade e instabilidade, por exemplo, fica expresso na relação entre contraditórios (alteridade e não agregação) em que não se passa diretamente para o estado de disjunção, mas para o de não identidade. Nesse sentido, a abordagem semiótica do discurso é aderente ao conceito de IO que contemple aspectos mais fluidos, dinâmicos, instáveis e múltiplos. À vista disso, ela pode ser compreendida como um processo contínuo de reconstrução, como defendem Ghadiri e Davel (2006).

Depois da apresentação dos fundamentos da teoria semiótica do discurso e de sua articulação com IO, o próximo tópico discorre sobre a proposição de uma estrutura de análise de texto em Estudos Organizacionais, ilustrado por meio de uma narrativa fictícia. 


\section{NARRATIVA FICTÍCIA}

A narrativa fictícia foi elaborada com o propósito de ilustrar a aplicação da análise semiótica do discurso. Elaborada pelos autores, a narrativa condensa um conjunto de ocorrências reais ocorridas no início do período de pós-privatização de uma estatal de grande porte do setor de prestação de serviços, adquirida por um grupo estrangeiro. A narrativa discorre sobre as circunstâncias vivenciadas por com um alto executivo, bem-sucedido, que trabalhava há mais de dez anos na empresa estatal privatizada.

\section{Quadro 1}

\section{Narrativa fictícia}

“[...] Aprendi muito na empresa e devo grande parte da minha capacitação profissional à essa empresa [...] mas, houve uma época em que a direção da empresa, apesar de prezar-me como ótimo profissional, não tinha mais condições de manter-me por mais tempo, por conta de um mal momento de conjuntura de mercado e queda abrupta dos negócios.

[...] fui aconselhar-me com a direção da empresa, sobre o meu desejo de ser empresário abrindo um negócio próprio de preferência no mesmo seguimento em que atuava, ah, uma ideia que tive é que esse negócio poderia ser por meio da terceirização dos serviços que eu vinha fazendo na empresa, mas eu estava um pouco inseguro, sabe, essa coisa de capital inicial, o primeiro contrato, o risco [...].

Em nome dos bons serviços prestados, conversei com a direção da empresa, se poderiam ajudar nessa nova empreitada, me dando uma encomenda para que pudesse iniciar as atividades, fornecendo o que lá antes eu fazia, mas já como pequeno empresário. Lembro quando me disseram:

[...] nós temos convicção de que você terá sucesso na sua própria empresa como obteve aqui na nossa.

A direção da empresa de fato me incentivou, lembro que me apontaram uma linha de crédito que estavam sendo pleiteadas pela ANMPE (Associação Nacional dos Micro e Pequenos Empresários) o que poderia ajudar-me para começar o negócio. Aí fiquei ainda mais confiante. [...] Além disso, me prometeram uma boa encomenda que permitisse viabilizar o início do meu almejado negócio próprio.

[...] é, eles cumpriram o que me prometeram.

Decidi e abri a minha empresa."

O profissional comenta que nos 10 anos seguintes a sua empresa cresceu e está, no momento, em ótima situação financeira, por conta dos desafios vencidos, da iniciativa em desenvolver novos negócios, o que permitiu ampliar a sua participação no seu mercado. O trecho, a seguir, ilustra tal situação:

“[...] isso se deve ao fato de que sempre estou bem à frente dos negócios, centralizo as decisões, sei que possuo uma disposição inabalável para trabalhar e mantenho um punho forte no comando de minha equipe de funcionários.

[...] porém, o tempo está passando e agora estou preocupado com a sucessão, pois não tenho parentes direto na empresa, e mais, não consigo perceber em nenhum de meus funcionários preparo ou pelo menos características que possam atender o meu processo sucessório. A hipótese de vender a empresa está descartada."

O profissional, e agora empresário, mostra-se incerto sobre o futuro de seu negócio.

Fonte: Elaborado pelos autores. 


\section{UM CAMINHO METODOLÓGICO DE ANÁLISE SEMIÓTICA DO DISCURSO: A ANÁLISE DA NARRATIVA}

Embora a literatura sobre a semiótica, mais precisamente no que se refere aos três níveis do percurso gerativo de sentido, os apresente partindo do nível fundamental e daí passando para os níveis narrativos e discursivos, respectivamente, sugere-se que uma análise dos textos das entrevistas deva ser feita de forma inversa. É, então, recomendável partir-se dos estudos narrativos e discursivos do texto em direção ao seu nível mais abstrato, ou seja, o nível fundamental, uma vez que nesse nível a rede de relações presentes na narrativa do texto converge para uma única relação que se manifesta por oposição ou diferença (BARROS, 1997) e "que estão na base da construção do texto" (FIORIN, 2011, p. 21). É, portanto, no nível fundamental que se revela o mínimo de sentido que organiza o texto, adiciona Barros (2012). Como recurso de base para a elaboração de uma análise semiótica dos discursos sugere-se analisar o corpus (por exemplo, a narrativa fictícia), considerando-se os seguintes elementos dos níveis narrativos e discursivos, concluindo com o nível fundamental.

\section{NÍVEL NARRATIVO}

Esse tópico analisa, sinteticamente, o percurso gerativo de sentido na organização narrativa e seus mecanismos sintáxicos e semânticos (Fig. 3), definindo os sujeitos e seus objetos-valor, o programa de competências e a realização de perfórmance, além do contrato à sanção.

\section{SUJEITOS E VALORES}

A análise semiótica dos textos poderia ser iniciada com a organização do nível narrativo sintático, que consiste, resumidamente, em descrever a cena, determinar seus participantes e o papel que representam na "história" contada por sujeito per se entrevistado (BARROS, 1997). Inicialmente, isso significa definir os atores, suas relações por conjunção ou disjunção com os respectivos objetos-valor e suas ações na busca dos valores investidos nos objetos-valor, mudando assim o estado das coisas, em cada percurso narrativo. Nessa fase, percebem-se os elementos de identificação (conjunção) e diferenciação (disjunção) dos sujeitos da narrativa em relação aos objetos-valor.

Tomaremos por base a narrativa fictícia acima citada, do profissional que desejava ter o seu negócio próprio. Em sua entrevista relata que estava empregado em uma empresa, que, apesar de prezá-lo como profissional, não tinha mais condições de mantê-lo por mais tempo. Esse profissional (sujeito) manifesta em seu discurso, o desejo de tornar-se empresário (conjunção), abrindo um negócio próprio (objeto-valor), como constatado dos fragmentos da entrevista "fui aconselhar-me com a direção da empresa, sobre o meu desejo de ser empresário abrindo um negócio próprio". A empresa onde ele trabalha se dispôs a ajudá-lo nessa empreitada e o fez como relatado nos fragmentos da entrevista:

[...] em nome dos bons serviços prestados, conversei com a direção da empresa, se poderiam ajudar nessa nova empreitada, me dando uma encomenda para que pudesse iniciar as atividades [...] A direção da empresa me incentivou, [...] me prometeram uma boa encomenda que permitisse viabilizar o início do meu almejado negócio próprio, [...] é, eles cumpriram o que me prometeram.

\section{PROGRAMA DE COMPETÊNCIAS}

O percurso do sujeito desenvolve-se com as transformações ensejadas pelos sujeitos por meio de aquisição de competências proporcionadas pelos destinadores-manipuladores com base em contratos estabelecidos entre esses e os sujeitos dos discursos. No exemplo, a aquisição de competência se dá pelo exercício das atividades do sujeito - profissional, na empresa 
(manipulador-destinador) em que está contratado (contrato) e que propicia o conhecimento necessário para abrir seu negócio próprio (adquire competência). Esse fato está presente no fragmento em que o profissional como sujeito destinatário comenta: "Aprendi muito na empresa e devo grande parte da minha capacitação profissional à essa empresa".

\section{REALIZAÇÃo DE PERFÓRMANCE E DO CONTRATO À SANÇÃo}

Por meio dos contratos estabelecidos entre os sujeitos e os destinadores manipuladores (explícitos ou não), os primeiros podem adquirir as competências necessárias para desempenhar as transformações pretendidas (programa de perfórmance). Seu sucesso ou insucesso poderá ser instrumentalizado pelo destinador sob a forma de uma recompensa ou sanção. No exemplo acima, tendo obtido a competência pelo tempo de trabalho como contratado da empresa, o profissional poderá desligar-se dessa, para abrir sua empresa (perfórmance), como citado no fragmento "houve uma época em que a direção da empresa, apesar de prezar-me como ótimo profissional, não tinha mais condições de manter-me por mais tempo", e aí a oportunidade de realizar o sonho de ter um negócio próprio (sanção positiva do cumprimento do contrato) como consta do fragmento, "é, eles cumpriram o que me prometeram. Decidi e abri a minha empresa". No percurso do destinador-manipulador este pode se valer de estratégias de manipulação em sua narrativa, como sedução, persuasão, intimidação ou tentação, a fim de transformar as ações do sujeito em busca do alcance de seu objetivo em relação ao objeto-valor. No exemplo do profissional, o manipulador (empresa) adotou uma estratégia de sedução como no fragmento: "nós temos convicção de que você terá sucesso na sua própria empresa como obteve aqui na nossa".

A última fase da organização narrativa é a do percurso do destinador-julgador que responde pela sanção do sujeito. No exemplo, a nova empresa recebe uma encomenda do antigo empregador possibilitando o início de suas atividades, constante do fragmento "Além disso, me prometeram uma boa encomenda que permitisse viabilizar o início do meu almejado negócio próprio, [...] é, eles cumpriram o que me prometeram".

Nos programas do nível narrativo verifica-se a transformação do estado das coisas em que o profissional investido do objeto-valor de se tornar empresário o faz com o apoio da direção da empresa como destinador-julgador, a qual sanciona positivamente o contrato com o sujeito-destinatário com o qual compartilha o mesmo sistema de valores - trabalho, empresa, negócio e oportunidade profissional - interpretando as ações e os resultados da mudança em questão como verdadeiros. O profissional assim agiu pela conjunção na busca do objeto-valor (valores modais), inscritos nas narrativas do profissional, que quer, deve, sabe e pode fazer o necessário, a perfórmance de iniciar seu negócio próprio.

\section{NÍVEL DISCURSIVO}

Esse tópico analisa, sinteticamente, o percurso gerativo de sentido no nível discursivo e seus aspectos sintáxicos e semânticos (consultar a Fig. 4), abordando os mecanismos estratégicos do discurso, temas e figuras.

\section{MECANISMOS ESTRATÉGICOS DO DISCURSO}

No nível sintático discursivo, são examinadas as estratégias adotadas pelo sujeito, enunciador do discurso visando a uma ação de convencimento da "veracidade" ou efeito de realidade de seu discurso. Nessa fase, então o sujeito se vale, entre outros, das estratégias de debreagem (ou desembreagem) e embreagem, que proporcionam o efeito de aproximação e subjetividade ou afastamento e objetividade em seu discurso, ou ainda da debreagem interna muito usada pelos noticiários dos veículos de comunicação. Como exemplo de debreagem interna para produzir efeito de realidade, na narrativa fictícia, podemos citar: "O Ministro do Comércio e Indústria disse que mais da metade das novas empresas abertas nos últimos cinco anos acabaram fechando por falta de preparo e capital de seus fundadores". 


\section{TEMAS E FIGURAS}

Nesse nível que se refere à semântica discursiva, emergem os temas como componentes abstratos e revestidos ideologicamente dos discursos. Porém os temas elencados muitas vezes carecem de se tornar tangíveis nos discursos. Com esse propósito os sujeitos da enunciação se apropriam de figuras com o objetivo de dar concretude a seus discursos, como forma de convencimento da veracidade de sua fala. Na narrativa o entrevistado comenta o fato de que a Associação Nacional dos Micro e Pequenos Empresários (ANMPE) reivindicava mais crédito a longo prazo para reduzir o fechamento prematuro de seus associados e ratificada no fragmento da sua entrevista "lembro que me apontaram uma linha de crédito que estavam sendo pleiteadas pela ANMPE, o que poderia ajudar-me para começar o negócio. Aí fiquei ainda mais confiante". A ANMPE é uma figurativização presente no discurso com o objetivo de proporcionar o "efeito de realidade" (BARROS, 1997, p. 59).

Os temas abordados nos discursos e materializados pela figurativização podem ser relacionados aos elementos de conjunção ou disjunção, não conjunção e não disjunção dos sujeitos em relação às abordagens presentes nos temas. A título de exemplo, um dos temas abordados no relato acima é o empreendedorismo.

O emprego da análise semiótica do discurso nos estudos de 10 deverá abranger um conteúdo mais amplo do que a breve exemplificação que abordou alguns itens de natureza narrativa e discursiva. A especificidade de cada estudo, a sensibilidade dos pesquisadores, a qualidade do corpus, o contexto sócio-histórico são aspectos relevantes na aplicação da análise semiótica do discurso nos temas organizacionais.

\section{NÍVEL FUNDAMENTAL: O QUADRADO SEMIÓTICO}

O tópico dedica-se à formulação das relações de oposições contrárias e contraditórias presentes no relato fictício, destacado na Figura 7.

No âmbito dos estudos em IO, tanto os enunciados de estado quanto os temas podem proporcionar os aspectos da organização com os quais seus membros se identificam (identificação organizacional), mas também aspectos em que esses se diferenciam, ou que assimilam ou ainda singularizam, como apresentado na Figura 5. E, por meio desses elementos de identificação, pode-se evoluir para os temas mais profundos de natureza abstrata presentes no nível fundamental, na busca das principais características identitárias da organização.

As categorias de identificação, diferenciação e seus contraditórios, constantes do quadrado semiótico que expressa o nível fundamental, apresentam-se como elementos significativos nos estudos da mudança ou formação identitária nas organizações.

Na narrativa fictícia, a nova empresa foi aberta pelo sujeito-profissional há mais de dez anos. Suponhamos que o empreendedorismo foi um atributo identitário central e distintivo que permaneceu ao longo desses anos e que a distinguia em relação às demais empresas de seu contexto de negócio. Na entrevista o sujeito-profissional afirma que exerce um estilo centralizador de gestão, indicando não oferecer autonomia a seus membros, mesmo os de nível gerencial, como visto no fragmento:

[...] isso se deve ao fato de que sempre estou bem à frente dos negócios, centralizo as decisões, sei que possuo uma disposição inabalável para trabalhar e mantenho um punho forte no comando de minha equipe de funcionários.

Pelo uso da semiótica do discurso, depreendem-se os atributos de oposição, por meio dos quais os membros ou grupos na organização se diferenciam (diferenciação). Na narrativa fictícia isso é expresso pelo conformismo como categoria oposta de alteridade.

A análise semiótica permite ainda revelar aspectos de não alteridade (agregação) como a falta de autonomia pela centralização decisória, como característica identitária da organização, agora de natureza ambígua, tensional e provisória, pois mesmo que, temporariamente, os membros assimilem essa falta de autonomia, esta poderá levar ao desestímulo no empenho das atividades, redução de comprometimento e até o desligamento da organização. 
Outra categoria, no exemplo, reveladora de atributos de natureza ambígua, tensional e provisória apontada no nível fundamental pelo quadrado semiótico, é a da não identidade (segregação) como a descentralização, uma vez que a direção da organização em algum momento necessita evoluir pela idade, por novos negócios ou por outros motivos. Para que haja continuidade há a necessidade de formação de novas lideranças e para tal a importância de concessão de autonomia a seus membros. Assim, a descentralização, embora seja em um primeiro momento uma não identidade, como característica, encontrando-se isolada (segregada), poderá ser fonte de preocupação e de continuidade da organização, como relatado no fragmento a seguir:

[...] porém, o tempo está passando e agora estou preocupado com a sucessão, pois não tenho parentes direto na empresa, e mais, não consigo perceber em nenhum de meus funcionários preparo ou pelo menos características que possam atender o meu processo sucessório.

Esse exemplo está representado no quadrado semiótico (Fig. 7), adaptado a partir da Figura 6 (LANDOWSKI, 2002; PIETROFORTE, 2008).

Figura 7

\section{Quadrado Semiótico de Identidade e Alteridade}

$\begin{array}{|ll|}\text { EMPREENDEDORISMO } & \begin{array}{l}\text { CONFORMISMO } \\ \text { (Disjunção) }\end{array} \\ \text { (Conjunção) } & \text { Alteridade } \\ \text { Agregação } & \text { Segregação } \\ \text { (Não disjunção) } & \text { (Não conjunção) } \\ \text { CENTRALIZAÇÃO } & \text { DESCENTRALIZAÇÃO }\end{array}$

Fonte: Adaptado de Landowski (2002) e Pietroforte (2008).

O empreendedorismo havia sido apontado como o atributo, central e de certa duração, conforme proposto por Albert e Whetten (1985) na definição seminal de IO. No entanto, com o uso da semiótica do discurso a identidade da organização exemplificada se revela agora com novos elementos da construção identitária organizacional por meio da segregação, como uma não identidade ligada à falta de autonomia dos funcionários.

A agregação consta do quadrado semiótico como não alteridade ligada ao processo decisório em oposição ao conformismo (alteridade). Na oposição contraditória há um caráter possível de transitoriedade, instabilidade e tensão entre estados de junção opostos (LANDOWSKI, 2002). Esses elementos revelados estão ligados; a falta de autonomia e a sucessão são de natureza instável e podem comprometer ou desestabilizar o caráter estável e duradouro da empresa que havia sido apontado como só o empreendedorismo. 


\section{CONSIDERAÇÕES FINAIS}

O artigo apresenta uma proposta metodológica, preponderantemente, para a condução de pesquisas sobre IO, fundamentada na análise semiótica dos discursos organizacionais, inspirada em Greimas.

O emprego de elementos da teoria semiótica do discurso apresenta-se como um importante recurso teórico-metodológico que permite transcender a formulação tradicional da IO de Albert e Whetten (1985), revelando atributos latentes engendrados das relações entre contrários, contraditórios e complementares. Portanto, é uma abordagem que oferece um recurso analítico aos questionamentos teóricos sobre a limitação conceitual unicamente baseada nos atributos centrais, distintivos e duradouros, para, dessa maneira, obter a possibilidade de se expandir para perspectivas mais dinâmicas e fluidas de IO.

Esses elementos, como na narrativa apresentada, revelam aspectos de alteridade na organização, considerando que a identidade se constrói não só com as características de conformidade, mas também em relação ao oposto, ou seja, com as características de desconformidade (BARROS, 2013). Refere-se, assim, não só ao que a organização é, mas ao que não quer ser. Além disso, o quadrado semiótico pode revelar elementos identitários referentes a "o quê" a organização pode vir a ser, dotados de tensão e de provisoriedade. Dessa condição, podem emergir ações e reações dos e entre os atores organizacionais com implicações sobre o(s) atributo(s) que até então personificava(m) uma organização. Isso posto, a análise semiótica revela, ao mesmo tempo, atributos da IO e a dinâmica de como essa identidade é formada e reconstruída no contexto organizacional, em um movimento tensional para responder às pressões externas e às necessidades internas dos diferentes stakeholders.

A perspectiva de IO como dinâmica, fluida e efêmera (CALDAS e WOOD JR., 1997; GIOIA, SCHULTZ e CORLEY, 2000; SCOTT e LANE, 2000; GHADIRI e DAVEL, 2006; CARRIERI, PAES-DE-PAULA e DAVEL, 2008; GIOIA, PATVARDHAN, HAMILTON et al., 2013), articulada metodologicamente com a abordagem semiótica do discurso, propicia contribuições tanto para a pesquisa quanto para a gestão. Teoricamente, contribui para revelar um entendimento ampliado das dimensões conceituais de IO. Em termos práticos, gera conhecimento aos gestores para interpretar a identidade da organização, não como um atributo estático e central, mas como a organização é e o que poderá vir a ser. Dessa forma, iluminam-se possibilidades de reconstrução da IO.

O quadrado semiótico impõe uma disciplina lógica (GREIMAS, 1976; BARROS, 1997; LANDOWSKY, 2002; PIETROFORTE, 2008), como fora aplicado na análise da narrativa fictícia. A proposta metodológica sugerida neste artigo, contudo, precisa ser empiricamente evidenciada num contexto organizacional, podendo ser objeto de pesquisas futuras.

Estudos que defendem a dinamicidade e fluidez da IO apontam para a necessidade de uma transformação paradigmática. Gioia, Schultz e Corley (2000) pontuam que os acadêmicos continuam a subestimar, menosprezar e inadequadamente desenvolver as implicações de conceitualizar a identidade como dinâmica. Os estudos de IO genericamente apresentam foco na formação da IO, na sua construção ou na sua mudança (GIOIA, PRICE, HAMILTON et al., 2010). É factível considerar que a análise semiótica do discurso possa subsidiar analiticamente a construção e a mudança da IO, com possível preponderância das estruturas narrativas, no caso de construção da identidade, e ênfase das estruturas discursivas, para mudança da IO e da imagem da organização. Apesar da potencialidade apontada, a análise semiótica do discurso na investigação da IO apresenta algumas limitações.

Os estudos de 10 envolvem vários atores sociais, internos e externos, dados primários e secundários produzidos pelas organizações. A análise desse corpus passa necessariamente pelo exame singular do percurso gerativo de sentido de cada fonte. O resultado do processo de consolidação do extenso material analisado para apreender a IO pode resultar em uma ênfase na tematização e na figurativização em prol da necessidade de um esforço voltado à agregação dos dados. Com isso, a riqueza de detalhes provenientes da análise das estruturas narrativas e discursivas, heterogêneas pela própria idiossincrasia dos diferentes discursos dos atores sociais, torna-se, pragmaticamente, inconciliável. No entanto, essas especificidades podem ser exploradas para explicar o caráter não duradouro da IO.

O levantamento feito por Ravasi e Canato (2013) aponta expressivo uso da teoria fundamentada de dados, sobretudo para depreender aspectos não contemplados na literatura com relação à formação da IO. Nesse caso, uma técnica de análise de dados propícia. A análise semiótica do discurso não nos parece uma ferramenta dirigida para a construção de teoria. Por outro lado, quando comparada à análise de conteúdo ou a outras vertentes de análise do discurso pode oferecer uma vantagem 
uma vez que permite enxergar a identidade e a identificação a partir das relações semânticas de contrários, contraditórios e complementares, essencial na perspectiva dinâmica da IO.

Condizente com as limitações acima apresentadas, a análise semiótica do discurso constitui uma ferramenta que exige um trabalho analítico manual minucioso do pesquisador. Até esse momento, considera-se que dificilmente esse tipo de análise poderia ter o apoio de softwares de análise qualitativa de dados.

A análise semiótica, na qualidade de um recurso metodológico, não se restringe à investigação empírica em IO. É pertinente ao campo dos estudos organizacionais, notadamente em cultura organizacional, bem como em estratégia e marketing, como observado no levantamento feito no sistema SPELL. Portanto, há um vasto terreno a ser explorado.

Como menção final, mas não menos importante, salienta-se que a análise semiótica da IO revela uma identidade discursiva. Assim sendo, diferentes discursos podem coexistir em uma organização, a partir das diferentes identidades sociais dos sujeitos falantes, pois a identidade discursiva é sempre algo "a construir em construção" (CHARAUDEAU, 2009, p. 10). 


\section{REFERÊNCIAS}

ALBERT, S. Temporal comparison theory. Psychological Review, v. 84, n. 6, p. 485-503, 1977.

ALBERT, S. The definition and metadefinition of identity. In: WHETTEN, D. A.; GODFREY, P. C. (Org.). Identity in organizations. Thousand Oaks, CA: Sage, 1998. 1-13 p.

ALBERT, S.; WHETTEN, D. Organizational identity. In: CUMMINGS, L. L.; STAW, B. M. (Org.). Research in organizational behavior. Greenwich: JAI Press, 1985. v. 7. 263-295 p.

ASHFORTH, B. E.; MAEL, F. Identity theory and the organization. Academy of Management Review, v. 14, n. 1, p. 20-39, 1989.

BARLEY, S. R. Semiotics and the study of occupational and organizational culture. Administrative Science Quarterly, v. 28, n. 3, p. 393-413, 1983.

BARROS, D. L. P. Teoria semiótica do texto. São Paulo: Ática, 1997. BARROS, D. L. P. Semiótica do discurso. Notas de aula de Teoria Semiótica. São Paulo: Universidade Presbiteriana Mackenzie, 2012. Não publicado.

BARROS, D. L. P. Semiótica do discurso. Notas de aula de Teoria Semiótica. São Paulo: Universidade Presbiteriana Mackenzie, 2013. Não publicado.

BENCHERKI, N.; COOREN, F. Having to be: the possessive constitution of organization. Human Relations, v. 64, n. 12, p. 1579-1607, 2011. BORGES, J. F.; MEDEIROS, C. R. O. “Aprecie com moderação": a identidade da organização como drama e atos de performance. Revista de Administração de Empresas, v. 51, n. 2, p. 132-142, 2011.

BROWN, A. D. Narcissism, identity, and legitimacy. Academy of Management Review, v. 22, n. 3, p. 643-686, 1997.

BROWN, S. L.; EISENHARDT, K. M. The art of continuous change: linking complexity theory and time-paced evolutions in relentlessly shifting organizations. Administrative Science Quarterly, v. 42, n. 1, p. 1-34, 1997.

BUNCHAFT, A. F.; GONDIM, S. M. G. Grupos focais na investigação qualitativa de identidade organizacional: exemplo de aplicação. Estudos de Psicologia, v. 21, n. 2, p. 63-77, 2004.

CALDAS, M. P.; WOOD JR., T. Identidade organizacional. Revista de Administração de Empresas, v. 37, n. 1, p. 6-17, 1997.

CARRIERI, A. P.; PAES-DE-PAULA, A. P.; DAVEL, E. Identidade nas organizações: múltipla? Fluida? Autônoma? Organizações \& Sociedade, v. 15, n. 45, p. 127-144, 2008.

CARVALHO, J. L. F. et al. A universidade como (re)produtora de estruturas de significados: uma análise semiótica institucional. Revista ADM.MADE, v. 14, n. 1, p. 1-21, 2010.

CAVEDON, N. R.; STEFANOWSKI, F. L. O riso que integra, o riso que separa: identidade organizacional em um sebo de Porto Alegre. Organizações \& Sociedade, v. 15, n. 46, p. 137-152, 2008.

CHARAUDEAU, P. Identidade social e identidade discursiva, o fundamento da competência comunicacional. 2009. Disponível em: $<\mathrm{http}: / /$ www.patrick-charaudeau.com/Identidade-social-e-identidade.html>. Acesso em: 15 maio 2015.

DANO, F.; ROUX, E.; NYECK, S. Les hommes, leur apparence et les cosmétiques: approches socio-sémiotiques. Décisions Marketing, v. 29, p. 7-18, 2003.

DUTTON, J. E.; DUKERICH, J. M. Keeping an eye on the mirror: image and identity in organizational adaptation. Academy of Management Journal, v. 34, n. 3, p. 517-554, 1991.
DUTTON, J. E.; DUKERICH, J.; HARQUAIL, C. Organizational images and members identification. Administrative Science Quarterly, v. 39, n. 2, p. 239-263, 1994.

ELSBACH, K. D.; KRAMER, R. M. Members' responses to organizational identity threats: encountering and countering the Business Week rankings. Administrative Science Quarterly, v. 41, n. 3, p. 442-476, 1996.

ÉSTHER, A. B. A construção da cultura e da identidade organizacionais na empresa familiar de pequeno porte: o papel do empreendedor fundador. Revista Organizações em Contexto, v. 10, n. 20, p. 205-242, 2014.

FARIA, M. D.; CARVALHO, J. J. F. Uma análise semiótica do potencial mercadológico da imagem de atletas paraolímpicos. Gestão e Sociedade, v. 4, n. 9, p. 657-688, 2010.

FERNANDES, M. E. R.; MARQUES, A. L.; CARRIERI, A. P. Identidade organizacional e os componentes do processo de identificação: uma proposta de integração. Cad. EBAPE.BR, v. 7, n. 4, p. 687-703, 2009. FIOL, C. A semiotic analysis of corporate language: organizational boundaries and joint venturing. Administrative Science Quarterly, v. 34, n. 2, p. 277-303, 1989.

FIORIN, J. L. As astúcias da enunciação: as categorias de pessoa, espaço e tempo. São Paulo: Ática, 1999.

FIORIN, J. L. Elementos de análise do discurso. São Paulo: Contexto, 2011. FISHER, C. HRD attitudes: or the roles and ethical stances of human resource developers. Human Resource Development International, v. 8, n. 2, p. 239-255, 2005.

FLOCH, J. M. Sémiotique, marketing et communication. Paris: PUF, 1995. FLOCH, J. M. A contribuição da semiótica estrutural para o design de um hipermercado. Galaxia, v. 14, n. 27, p. 21-47, 2014.

GHADIRI, S.; DAVEL, E. Do sólido ao fluido: contradição organizacional e paradoxo na reconstrução de identidade. RAE-Eletrônica, v. 5, n. 1, 2006.

GIOIA, D. A. From individual to organizational identity. In: WHETTEN, D. A.; GODFREY, P. C. (Org.). Identity in organizations. Thousand Oaks, CA: Sage, 1998. 17-31 p.

GIOIA, D. A.; CHITTIPEDDI, K. Sensemaking and sensegiving in strategic change initiation. Strategic Management Journal, v. 12, p. 433-458, 1991.

GIOIA, D. A.; SCHULTZ, M.; CORLEY, K. G. Organizational identity, image and adaptative instability. Academy of Management Review, v. 25, n. 1, p. 663-681, 2000.

GIOIA, D. A. et al. Forging an identity: an insider-outsider study of process involved in the formation of organizational identity. Administrative Science Quarterly, v. 55, n. 1, p. 1-46, 2010.

GIOIA, D. A. et al. Organizational identity formation and change. The Academy of Management Annals, v. 7, n. 1, p. 123-193, 2013. GREIMAS, A. Semântica estrutural. São Paulo: Cultrix, 1976.

GREIMAS A.; COURTÉS, J. Dicionário de semiótica. São Paulo: Contexto, 2011.

HATCH, M.; SCHULTZ, M. Relations between organizational culture, identity and image. European Journal of Marketing, v. 31, n. 5/6, p. 356-365, 1997.

HATCH, M.; SCHULTZ, M. The dynamics of organizational identity. Human Relations, v. 55, n. 8, p. 989-1018, 2002.

IPIRANGA, A. S. R. A narração fílmica como instrumento da ação formativa: um enfoque semiótico. Organizações \& Sociedade, v. 12, n. 32, p. 143-164, 2005. 
KESSOUS, A.; ROUX, E. A semiotic analysis of nostalgia as a connection to the past. Qualitative Market Research: An International Journal, v. 11, n. 2, p. 192-212, 2008.

LANDOWSKI, E. Presenças do outro. Ensaios de sociossemiótica. São Paulo: Perspectiva, 2002.

MACHADO, H. V. Identidade organizacional: um estudo de caso no contexto da cultura brasileira. RAE-Eletrônica, v. 4, n. 1, p. 1-18, 2005

MACHADO-DA-SILVA, C. L.; NOGUEIRA, E. E. S. Identidade organizacional: um caso de manutenção, outro de mudança. Revista de Administração Contemporânea, v. 5, n. Edição Especial, p. 35-58, 2001. MICK, D. G.; OSWALD, L. R. The semiotic paradigm on meaning in the marketing place. In: BELK, R. W. (Ed.). Handbook of qualitative research methods in marketing. Northampton, MA: Edward Elgar, 2006. 31-45 p.

MIGUEL, L. A. P.; POPADIUK S. Integrando metodologias na análise de dados sob o paradigma interacionista simbólico: um caso prático. Cad. EBAPE.BR, v. 12, n. 2, p. 357-373, 2014.

MIRANDA, L. C. et al. Da Mesopotâmia às tapioqueiras de Olinda o pensamento contábil se revela. Revista de Educação e Pesquisa em Contabilidade, v. 5, n. 3, p. 24-47, 2011.

NOGUEIRA, E. E. S. Símbolo e identidade organizacional: função da figura ou imagem conceitual. RAC-Eletrônica, v. 1, n. 2, p. 81-96, 2007.

PATVARDHAN, S. D.; GIOIA, D. A.; HAMILTON, A. L. Weathering a meta-level identity crisis: forging a coherent collective identity for an emerging field. Academy of Management Journal, v. 58, n. 2, p. 405-435, 2015.

PESSÔA, L. A. G.; COSTA, A. S. M.; ESPÍRITO SANTO, P. O. Um estudo semiótico das estratégias narrativas da revista Exame acerca das comunidades virtuais. Revista Economia \& Gestão, v. 15, n. 38, p. 86-109, 2015.

PIETROFORTE, A. V. S. Tópicos de semiótica: modelos teóricos e aplicações. São Paulo: Annablume, 2008.

RAVASI, D.; CANATO, A. How do I know who you think you are? A review of research methods on organizational identity. International Journal of Management Reviews, v. 15, p. 185-204, 2013.
RISSONI, G. P. S. Estratégias enunciativas nos blogs jornalísticos: a resignificação do espaço editorializado em ambiente virtual. Revista Brasileira de Marketing, v. 6, n. 2, p. 133-140, 2007.

ROBICHAUD, D. Greimas' semiotics and the analysis of organizational action. In: LIU, K. et al. (Eds.). Coordination and communication using signs. New York: Springer, 2002. v. 2. 129-149 p.

ROCHA, C. B.; SILVA, J. R. G. Identificação de funcionários com empresa pública no contexto de mudanças: o caso Finep. Rev. Adm. Pública, v. 41, n. 4, p. 685-706, 2007.

SANT'ANA, V. A.; PESSÔA, L. A. G. "E se colocar pimenta?": análise semiótica da identidade da marca Chilli Beans. Revista ADM.MADE, v. 17, n. 3, p. 89-109, 2013.

SCOTT, S. G.; LANE, V. R. A stakeholder approach to organizational identity. Academy of Management Review, v. 25, n. 1, p. 43-62, 2000.

SOUZA, M. M. P.; CARRIERI, A. P. A arte de (sobre)viver coletivamente: estudando a identidade do Grupo Galpão. Revista de Administração, v. 48, n. 1, p. 7-20, 2013.

SOUZA, M. M. P.; CARRIERI, P.; FARIA, A. The construction of organizational identity: discourses on the Brazilian private railroad. Brazilian Administration Review, v. 5, n. 3, p. 177-192, 2008.

SVENINGSSON, S.; ALVESSON, M. Managing managerial identities: organizational fragmentation, discourse and identity struggle. Human Relations, v. 56, n. 10, p. 1163-1193, 2003.

TAJFEL, H. Social identity and intergroup relations. Cambridge, UK: Cambridge University Press, 1982.

TAJFEL, H.; TURNER, J. The social identity theory of intergroup behavior. In. WORSHEL, S.; AUSTIN, W. (Eds.). The psychology of intergroup relations. Chicago, IL: Nelson-Hall, 1986. v. 2. 7-24 p.

WHETTEN, D. Albert and Whetten revisited: strengthening the concept of organizational identity. Journal of Management Inquiry, $v$. 15, n. 3, p. 219-234, 2006.

Marco Antonio Fernandes Cardoso

Doutor em Administração de Empresas pela Universidade Presbiteriana Mackenzie; Professor convidado do programa de MBA em Administração de Empresas da FGV Management. E-mail: marco.cardoso@fgv.br

Darcy Mitiko Mori Hanashiro

Doutora em Administração pela Universidade de São Paulo; Professora Adjunta na Universidade Presbiteriana Mackenzie (UPM). E-mail: darcyhanashiro@gmail.com

Diana Luz Pessoa de Barros

Doutora em Linguística pela Universidade de São Paulo; Professora Associada Pleno na Universidade Presbiteriana Mackenzie (UPM). E-mail: diana. barros@mackenzie.br 